\title{
Bazı Mecaz ve Müteşâbih Ayetleri Doğru Anlama Metodolojisi
}

\author{
Hayati Aydin \\ Prof. Dr., Van Yüzüncü Yıl Üniversitesi, İlahiyat Fakültesi, Tefsir Ana Bilim Dalı \\ Van/Türkiye \\ aydinhayati@yyu.edu.tr \\ http://orcid.org/0000-0002-7652-6434
}

\begin{abstract}
Öz: Bilindiği gibi bazı ayetleri yorumlamada birtakım zorluklar yaşanmaktadır. Bunların başında da mecaz içerikli ve müteşâbih ayetler gelmektedir. Kur'ân'ın yoğun bir şekilde mecazı kullandığı ve onda gayba taalluk eden ayetlerin (müteşâbih) büyük bir yekün teşkil ettiği göz önüne alındığında konunun önemi ortaya çıkmaktadır. Büyük oranda bu ayetlerde Kur'ân kendi bütünlüğü içerisinde ele alınmadığı ve anlatım üslubu iyice bilinmediğinden anlama problemi aşılamamaktadır. Hâlbuki Kur'ân aşkın olandan içkin olana, beşeri teamülleri ve yapıyı esas alarak inmiş bir kelamdır. Dolayısıyla Kur'ân ayetlerini din bütünlügü içerisinde, beşerin teamülleri ve doğasını bilmekle ve Kur'ân'ın bu doğayla uyumunu kurmakla anlamak mümkündür. Kur'ân'da mecazın temsilî anlatımı çok yoğun kullanılmaktadır. Müteşâbihlerin bir kısmı özellikle ilahî sıfatlarda temsilî anlatım hâkim olduğu, bu konuda insan biçimci bir anlatımın tercih edildiği söylenebilir. Bu, "kııyasü'l-gâaib 'alesşşâhid" yani "bilinmeyen bir dünyayı bilinen dünyanın olgularına benzeterek anlatmak" olarak tanımlanır. Kur'ân'ın bu yolla gaybî hakikatleri ve psikolojik durumları bize kavratmakta olduğunu, bu anlatımla insan ufkunu aşan gaybî ve psikolojik durumları anlaşılır kıldığını, dinî hakikatleri zihne yaklaştırdığını söylemek mümkündür. Makalemiz mecaz konusunda, mecazı, mecazın hakikatle ilişkisini ve sadece mecazın kastedildiği bazı ayetleri ve özellikle temsilî anlatımı ve bundan da kâmin (gizli) temsili irdelemiş, müteşâbih konusunda ise müteşâbihi, müteşâbihleri muhkemlere irca etme, Kur'ân'ın üslup ve âdetini göz önüne alarak müteşâbihi bir metodoloji dahilinde anlamaya çalışma yoluna gitmiştir.
\end{abstract}

Anahtar Kelimler: Tefsîr, Kur’ân, Mecaz, Temsilî Anlatım, Müteşâbih.

Geliş Tarihi/Received Date: 13.07.2021

Kabul Tarihi/Accepted Date: 30.07 .2021

Araștırma Makalesi/Research Article

Atıf/Citation: Aydın, Hayati. “Bazı Mecaz ve Müteşâbih Ayetleri Doğru Anlama Metodolojisi”. Uludağ Üniversitesi İlahiyat Fakültesi Dergisi 30/2 (Aralık 2021), 599-631. https://doi.org/10.51447/uluifd.896328 


\title{
The Correct Methodology of Understanding Some Metaphorical and Mutashābih Verses
}

\begin{abstract}
As it is known, there are some difficulties in interpreting some verses. The most important of these are metaphorical verses and the verses with a profundity of meanings and a versatile content (mutashābih). Considering that the Qurān uses metaphors and the (mutashābih) verses that are characterized with the realm of the unseen (gayb) and which are challenging for our limited conceptualizations exist abundantly in the Holy Qur'ān, the importance of the issue becomes clear. In the Qur'ān, the representational expression of the metaphor is used extensively. It can be said that representational narration prevails especially in divine attributions, and an anthropomorphic expression is preferred in this regard. We can define this as "Qlyās al-gāib alā al-shahid", that is, to describe an unknown world by analogy with the phenomena of the known world. With this expression, it is possible to say that unseen and psychological situations that transcend the human horizon are made intelligible, and religious truths are brought closer to the mind in this way. Divine attributes were also described in this way, and an anthropomorphic expression was preferred for them. We examined the Metaphor and the relationship between metaphor and truth, and some verses in which only metaphor is meant, and especially representational narration. On the subject of mutashābih, issues such as mutashābih, adaptation of them to Muhkāmat and understanding the Qur'ān by taking into account the style of the Qur'ān have been tried to be resolved within a methodology.
\end{abstract}

Keywords: Tafsīr, Qur’ān, Metaphor, Representational Narration, Mutashābih.

[You may find an extended abstract of this article after the bibliography.]

\section{Giriş}

Kur'ân karakter itibarıyla ümmîlere inen bir kitap olup ifadeleri gayet sadedir. Ancak Kur'ân'ın edebî zevki olanlara da hitap eden bir yönü vardır. Bunun da en önemli unsuru mecaz ve müteşâbihlerdir. Çünkü mecaz, kelamda çok boyutluluk, edebî zevki olanların dikkatini çeken ve onların hoşlandığı bir hitap çeşididir. Mecazın hem söze canlılık hem de zarafet kazandırdı̆̆ı sıradan insanların bile malumu olmasına rağmen delalet ettiği anlamın tespiti kültürlü ve zeki insanlara mahsustur. Müteşâbihler de hem karakter hem de birden çok manaya delalet etmesi ve ikisinde de temsilî anlatımın kullanılması açısından mecaz gibi delalet noktasında problem oluşturmaktadır. Nitekim Aristoteles (M.Ö. 384-322), tartışmalarda sözcükler üzerinden hareket edenlerin, nesneler yerine sözcüklere dayandıkları ve dilsel ifadelerin nesnelerin hepsini kapsamamasına, sözcük ve kavramların niceliğinin sınırlı olmasına bağlı olarak akıl yürütmede hata edebileceklerine dikkat çekmiştir. ${ }^{1}$ İbn Sînâ (ö. 438/1037) da, Kitabu'ş-Şifầ'da mantık yanlışlarının genel sebebinin bir şeyin başka bir şeye benzemesi olduğunu, şeyler arasında benzerlik olmazsa yanlışlığın da oluşmadığını, bu benzerliklerin manalardan çok lafızlardan kaynaklandığı-

Aristoteles, Sofistlerin Çürütmeleri Üzerine, çev. Oğuz Özügül (İstanbul: Say Yayınları, 2007), 8. 
nı ifade etmektedir. ${ }^{2}$ Örneğin eş seslilik sebebiyle bir ismin birden çok şey için gerçekte veya istiâre ve mecazî bir kullanım dolayısıyla âdeten ortak olmasının yanılgılara kapı açtı̆̆ını söylemektedir. ${ }^{3}$

Aşkın olandan içkin olana gelen, sınırsız bir boyutu sınırlı dil imkânlarıyla anlatan din dilinin iyice anlaşılamaması nedeniyle birçok farklı yorumun ortaya çıkmasını da bu kategoride mütalaa etmek lazımdır. Özellikle bu sorun içinde mecazın yoğun kullanıldığı metafizik varlık alanıyla alakalı ifade ve konularda daha da belirgin olarak ortaya çıktığı söylenebilir. Nitekim Kur'ân'ın, kalplerinde eğrilik olanların te'vîl yoluna gidip bu alanla alakalı müteşâbihlere tutunduklarını söylemesi ${ }^{4}$ erken dönemde müteşâbihleri anlamada problem olduğunu ortaya koymaktadır. Her ne kadar selef(sahâbe ve tâbiîn)in ekseriyeti ihtiyat açısından müteşâbihlerde tevakkuf ve onları tefvîz (Allah'a havale etme) yolunu seçmiş olsa da insanların bu ayetlerde kastedileni öğrenme merakını dindirememiştir. Bir takım halef uleması ise problemin aşılması adına daha çok dil kullanımını esas alarak müteşâbihleri te'vîl yoluna gitmiş olsa da bazıları tarafından te'vîlin bir nevi tahrif olduğu söylenerek bu girişimler de dini çığırından çıkarmak olarak yorumlanmıştır. Erken sayılabilecek bir dönemde Müşebbihe ve Mücessime gibi akımlar müteşâbihleri zahiri üzerine anlayarak, teşbih ve tecsîme (antropomorfizme) gitmiştir. Mu`tezile ve Mürcie gibi bazı mezhepler düşüncelerine referans olsun diye zahiri anlamı te'vîl yoluna girerek mecaza hamletmeleri de müteşâbihleri anlama ile ilgili problemi daha da katmerli hale getirmiştir. Daha da ötesi Batınîler, Kur'ân ifadelerinin bir anlamda lafizlarla örülü sembollerden oluştuğunu ifade etmiş, mutasavviflar da beyan dairesinin sınırlarını aşarak geliştirdikleri irfanî kuramlar (keşf-müşâhede) ekseninde Kur'ân lafızlarına hamledilmesi mümkün olmayan anlamlar yüklemişlerdir. ${ }^{5}$

Bütün bunlar, bu gibi ayetlerin anlaşılmasında bir problemin olduğunu ortaya koymaktadır. Makalemiz gücü nispetinde bazı mecaz ve müteşâbih ayetlerde kastedilen anlamın ne olduğunu tespit etmeye çalışacak, bu gibi ayetlerde yanlış anlamayı bertaraf edecek bir metodolojiyle mevcut problemleri bir nebze çözmeye çalışacaktır. Bu bağlamda bazı konular ve müfessirlerin görüş açılarının tespitine dair akademik çalışmalar olsa $\mathrm{da}^{6}$ makalemiz onlardan farklı olarak bir metodoloji

\footnotetext{
Ebû Ali İbn Sînâ, Kitâbu'ş-Şifâ: Sofistik Deliller, çev. Ömer Türker (İstanbul: Litera Yayıncılık, 2006), 26.

İbn Sînâ, Kitâbu'ş-Şifâ: Sofistik Deliller, 9.

Âl-i İmrân 3/7.

5 Abdulmuttalip Arpa, “Zâhirîlik ve Mecâz: İbn Hazm Örneği”, Sakarya Üniversitesi İlahiyat Fakültesi Dergisi 14/25 (2012), 48-49.

6 Bu bağlamda bazı akademik çalışmalar olsa da en fazla konumuzla alakalı olanlardan Celil Kiraz, “Zemahşeri'nin el-Keşşâf'ında Allah'ın Bazı Sıfatlarıyla İlgili Temsîl, Mecâz ve İstiâre Algılamaları” (Uludağ Üniversitesi İlahiyat Fakültesi Dergisi 17/2 [2008], 519-568) adlı makalesinde Zemahşerî'nin görüşlerini Taberî, Mâtürîdî, İbn Atiyye ve Râzî ile karşılaştırmıştır. Veysel Güllüce, "Kâmin Mesellerin Değerlendirilmesi -İbn Fadl Örneğinde-” (Atatürk Üniversitesi İlahiyat Fakültesi Dergisi 25 [2006], 95-128) adlı çalışmasında atasözü anlamında Kur'ân mesellerine yaklaşmış, zaman zaman
} 
üzerinde hareket ederek sonuca ulaşmaya, farklı boyutlarıyla konuya irdelemeye çalışacaktır.

\section{Mecaz ve İlgili Bazı Ayetleri Anlama Metodolojisi}

Girişte ifade edildiği gibi Kur'ân ümmîlere inen bir kitap olmakla birlikte farklı insanlara da hitap etmektedir. Ancak ümmî derken bundan iki şey kastedilir. Biri, okuma yazma bilmeyen, ${ }^{7}$ ikincisi de kendilerine semavî kitap gelmeyenler. Kur'ân'da ise ikincisi yani kendilerine kitap gelmeyenler anlamında bu sözün kullanıldığını ifade etmek lazımdır. ${ }^{8}$

Kur'ân'ın edebî zevki olanlara hitap ettiğinin delillerinden birisi onun mecazı oldukça çok kullanmasıdır. Aslında mecazın, ifadelerin anlam alanını genişlettiğinden dolayı dinin farklı insanlara hitabında büyük işlev yerine getirdiğini belirtmek lazımdır. Mecaz, lügat olarak bir şeyin kendisine ait yerden başka yere konulması; ${ }^{9}$ ya da bir kelimenin konuluş amacının haricinde kullanılması olsa da ${ }^{10}$ st 1 lah olarak gerçek anlamın kastedilmesine engel olan bir karine ve bir alakanın varlığıyla ait olduğu anlamının dışında bir manada kullanılan kelime ve terkiptir. ${ }^{11}$ Bu şekilde bir kelime ve terkibin gerçek anlamının dışında kullanılması bir problemin habercisi

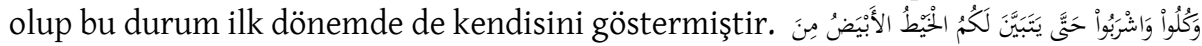
“Fecirden beyaz iplik siyah iplikten ayırt edilinceye kadar yiyin, için."12 ayeti inince Kur'ân'ın edebî yönüne vakıf olmayan veya edebî kültürü olmayan ashaptan Sehl b. Sa'd (r.a.) gibi ashaptan bazıları ayetin medlûlünü anlamada zorlanmışlardır. ${ }^{13} \mathrm{Bu}$ bağlamda Adî b. Hâtim'in (r.a.) biri siyah, biri beyaz iki köstek bağı aldığı ve gece vakti bunlara bakıp fecri anlamaya çalıştığı kaynaklarda zikredilmektedir. Ancak birini diğerinden ayırt edemediği, sabah olunca durumu

bunları Türk atasözleriyle eşleştirmiştir. Abdülmuttalip Arpa'nın, “Zâhirîlik ve Mecâz" adlı çalışmasında Kur'ân'da mecaz üzerinde durmuştur. Necdet Çağıl'ın ise, "Hakikat-Mecaz Kutuplaşması Bağlamında Kur’an'da Temsilî (Simgesel) Anlatım” (İslami İlimler Dergisi 8/1 [2013], 93112) adlı makalesinde Kur'ân'da temsilî anlatımlı ayetleri irdelemiştir. Sözkonusu bu çalışmaların kısmen örtüşen yönleri olsa da bazı mecaz ve müteşâbih ayetleri bir metodoloji çerçevesinde anlamaya çalışması nedeniyle makalemizin bunlardan ayrıştı̆̆ını belirtmek lazımdır.

7 Allah Resûlü'nün (s.a.v.) نحن أمة أمية لا نكتب ولا نحسب (Ebû Dâvûd Süleyman b. Eş`as es-Sicistânî, es-Sünen [Riyâd: Beytü'l-Efkâr, ts. ] "Savm," 4 [2319] hadisinde ümmî ifadesi okuma yazma bilmeyenler anlamında kullanılmıştır.

8 bk. Âl-i İmrân 3/20; el-Cuma 62/2.

9 Ebü'l-Hasan Ali b. Muhammed Seyyid Şerîf Cürcânî, et-Ta'rîfât (İstanbul: y.y., ts.), 203.

10 Ebü'l-Meâlî Celâleddîn el-Hatîb Muhammed b. Abdirrahmân el-Kazvînî, el-Îdâh fí 'ulûmi'l-belâga (Beyrut: Darü'l-Kütübi'l-ìlmiyye, 2003), 204.

11 bk. Hatîb el-Kazvînî, el-Ị̂̂ah fí 'ulûmi'l-belâga, 204.

12 el-Bakara 2/187.

13 Ebû Abdullah Muhammed b. İsmail el-Buhârî, el-Câmi'u'ṣ-ṣahîhh (Riyâd: Mektebetü'r-Rüşd, 2006), “Savm," 16 (1917). 
Resûlullah'a (s.a.v.) bildirerek, "Yastığımın altına biri siyah biri beyaz iki iplik koydum." dediği ve Resûlullah'ın (s.a.v.) ona latifede bulunarak, "Beyaz iplikle siyah iplik senin yastığının altında iseler gerçekten yastığın çok geniş olmalıdır." dediği rivayet edilmektedir. ${ }^{14} \mathrm{O}$ halde bu olayda olduğu gibi Kur'ân'ın bazı ifadelerini ancak edebî zevk sahibi olanların anlayabileceğini ya da en azından bazı ifadelerin içsel boyutunda hakikate tâbi artı anlamları bilmenin uzmanlara mahsus olduğunu söyleyebiliriz.

İbn Kuteybe (ö. 276/889) mütercimlerin, İncil'i Süryanice'den Habeş ve Rûm diline, Tevrat, Zebur ve diğer ilahî kitapları da Arapça'ya tercüme ettikleri gibi Arapların milletler arasında çok yaygın mecaz kullanmaları ve onların diliyle indiğinden Kur'ân'ı bir yabancı dile tercüme edemediklerini söylemesi ${ }^{15}$ bu gerçeği ortaya koymaktadır.

Bu gibi ayetleri anlamadaki zorluk konusunda İbn Kuteybe'nin şu ayetle ilgili tespiti yerindedir:

Bir kavimden bir hainlik endişe edersen (antlaşmayı bozduğunu) onlara bildir ki eşit olasınız..."16 ifadesinde hazfedilen lafizların tamamı zikredilmeden ayet anlaşılmaz. Yani "Seninle bir kavim arasinda barış ve antlaşma olur ve onların antlaşmayı bozarak hıyanette bulunacaklarından korkarsan onlarla yapmış olduğun antlaşmayı bozduğunu açıkça ilan et. Böylece onlarla antlaşmanın bozulduğuna dair bilme noktasında eșit olasınız. ${ }^{17}$

Ayette, antlaşmayı bozma eyleminin açıkça söylenmemesinin, karşı tarafın da bundan habersiz olmasının gayrı ahlaki olacağı, bir nevi antlaşmanın bozulduğundan habersiz birisini sırtından hançerlemek anlamına geleceği, bunun ise; dürüstlügü şiar edinmiş olan İslâm dinine aykırı olacağı ima edilmektedir. Bu hususa dikkat edildiğinde Kur'ân'ın ne kadar ince anlamlar barındırdığı, daha açık bir tabirle Kur'ân'ın bazı anlamları ima ile ifade etmek istediği anlaşılmaktadır.

Allah Resûlü (s.a.v.) de Hudeybiye barış antlaşması metnine, her türlü aldatmadan uzak, barışa vefa gösteren temiz bir kalp vardır, anlamında "Artık bizimle sizin aranızda kapalı bir aybe (sine) vardır." ifadesini yazdırarak ${ }^{18}$ sırrı saklayan insan göğsünü yiyecek ve elbiselerin saklandığı mekâna benzetmiştir. Ensardan gelen yardım için de "Ben Yemen tarafindan Rahmân'ın nefesini alıyorum." ${ }^{19}$ diyerek yardımı insanın yüreğini serinleten nefese benzetmesi örneklerinde anlaşıldığı üzere mecazî ifadeleri sıklıkla kullanmıştır.

14 Buhârî, “Savm”, 16 (1916); Ebü'l-Hüseyin Müslim b. Haccâc Müslim, Șaḥ̂hu Müslim (Riyâd: (Beytü'lEfkâri'd-Devliyye, 1998) "Sıyâm," 33 (1090); Ebû Dâvûd, "Savm," 17 (2349).

15 Ebû Muhammed Abdullah b. Müslim İbn Kuteybe, Te’vîlü müşkili’l-Ḳur’ân (Misır: Dâru’t-Turâs, 1973), 22.

16 el-Enfâl 8/58.

17 İbn Kuteybe, Te'vîlü müşkili'l-Kur'ân, 22.

18 İbn Kuteybe, Tevîlü müşkili'l-Kur’ân, 59-60.

19 İbn Kuteybe, Te’vîlü müşkili’l-Kur’ân, 59-60. 
Kur'ân'ın mecazî ifadelerinin daha teknik ve içlerinde hakikat vurgusunu da ta-

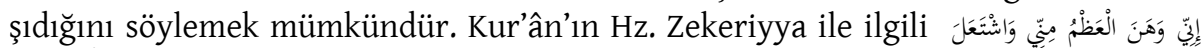

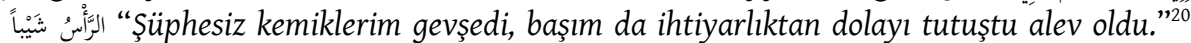
sözü, belagat erbabının saçın siyahlıkları arasındaki beyazları karanlıklar arasındaki parlayan yıldızlara benzetmesinden ${ }^{21}$ daha teknik ve edebî zevk sahiplerini daha

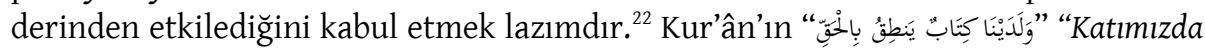
hakkı söyleyen bir kitap vardır." ${ }^{23}$ şeklindeki nitelemesinde, söylemek insana mahsus iken kitaba bu şekilde nutuk sıfatının verilmesinin, Kur'ân'ın hakkı söylemedeki hassasiyetini ifade ettiği söylenebilir. ${ }^{24}$ Çünkü burada kitabın (yani yazılı belgenin) şahitliğinin, insanın dille şahitliğinden daha güçlü olduğu hakikatine vurgu vardır. Ebû Ubeyde (ö. 209/824), Kur'ân'a Furkân denilmesinin nedenin de bu şekilde hakk1 batıldan, Müslümanı kâfirden ayırt etmesi ve hakkı ifade etmenin Kur'ân'ın bir sıfatı olduğunu söylemektedir. ${ }^{25}$ Aynı şekilde Kur'ân'da Hz. Mûsâ'nın öfkesinden

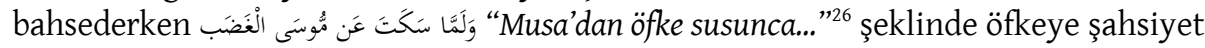
verilmesi öfkenin insana galip gelen ve insanı kontrol eden bir yönünün olduğunu

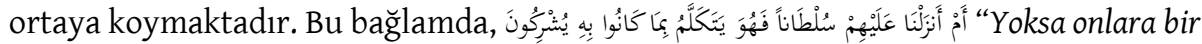
delil indirmişiz de o mu (Allah'a) ortak koştuklarını(n doğru olduğunu) söylüyor?”27 ayetinde delile konuşma sıfatının verilmesi, delilde konuşanın şehadeti gibi kuvvetli bir

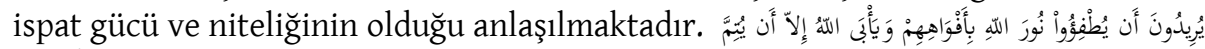
نAllah'ın nurunu ağızlarıyla söndürmek istiyorlar. Hâlbuki kâfirler hoşlanmasa da Allah, mutlaka nurunu tamamlamak ister."28 ayetinde kâfirlerin İslâm'1 yok edip tahrip etme hususundaki uğraşıları, tutuşmuş büyük bir ateşi üfürükle söndürmeye çalışan bir adamın fiiline benzetilmiştir. Bunda böylesine tutuşmuş büyük bir ateşi üfürükle söndürmeye çalışmanın çok gülünç ve cılız olduğuna bir nükte olmakla birlikle kâfirlerin bu derece zayıf hilelerle İslâm'ı yıkamayacakları, nurunu söndüremeyecekleri hakikatine de işaret vardır. ${ }^{29}$

Kur'ân'da mecazî mananın hakiki manaya tercih edilmesi gerekli olan bazı ayetler de vardır. Örneğin, Dönüp gitti mi (veya iş başına geçti mi) yeryüzünde bozgunculuk yapmağa, harsı (ekini) ve nesli

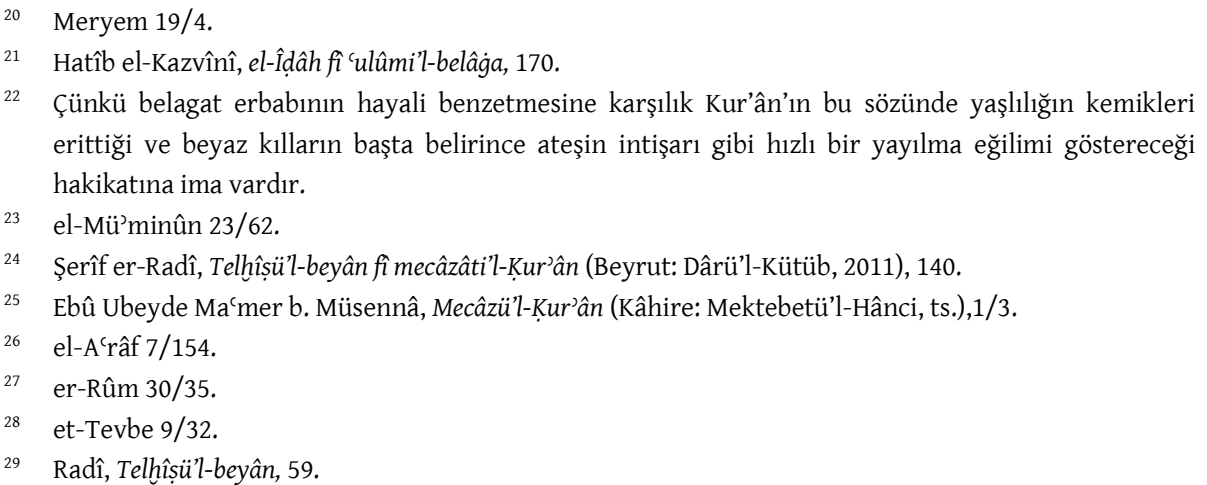


yok etmeğe başlar; Allah da bozgunculuğu sevmez."30 ayetinde "تََّّ" ifadesi hem arkasını dön(üp git)mek, hem de bir sorumluluğu yüklenmek anlamını taşımaktadır. Esbab-1 nüzûl kitaplarında ayetin, Allah Resûlü'nün (s.a.v.) yanına gelip İslâm'ını izhar ettikten sonra Müslümanların ekinlerini yakan münafiklardan Ahnes b. Şerîk esSekafî hakkında indiği söylense de ${ }^{31}$ "Sebebin hususiliğine değil lafzın umumiliğine bakılır.” tefsir kuralı ve ayetin bağlamı dikkate alındığında Kur'ân'ın iki tip insanın karakter analizini yaptı̆̆ı anlaşılmaktadır: Bir önceki ayette "Insanlardan öylesi var $k i$, dünya hayatına dair sözü, senin hoşuna gider... Oysa o, hasımların en yamanıdır." 32 derken kötü, sonrasında "Insanlardan öylesi var ki, canını, Allah'ın rızasını kazanmaya satar. Allah da kullar(ın)a çok şefkatlidir." 33 derken de iyi insan karakteri resmedilmektedir. Kur'ân'ın, "kadınlarınız sizin tarlanızdır..."34 sözüyle kadınları mecazî olarak tarlaya benzetmesinden hareketle, ayetin kötü karakterli insanların sorumluluk makamına geçtiklerinde namuslara musallat olabileceklerini ve nesli bozabilecekleri anlamına vurgu yaptığı anlaşılmaktadır. "Neslin", namus dışı ilişkiden sonra bozulduğu gerçeği unutulmamalıdır. Dolaysıyla ayette mecazî mananın ön planda olduğu söylenebilir. Aynı şekilde

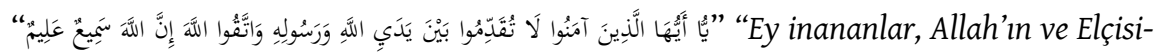
nin önüne geçmeyin." 35 ayetinde de mecazî anlamın ön planda olduğunu söyleyebiliriz. Ayetten kasıt, mekân olarak Allah ve Resûlü'nün önüne geçme değildir; böyle olsa Allah'ı geçmeyi bir yere koyamayız. Bu ifadeden amaç "Kanunları çiğnemeyiniz"dir. Öyleyse ayetin anlamı, "Ey iman edenler! Bir iş hakkında şahsi tercihlerinizle ve yargılarınızla hüküm beyan ederek Allah ve Resulünün buyruğuna karşı gelmeyiniz.” şeklindedir. Araplar, "filan, emirin önüne geçti" dediklerinde bu sözden amaçları, onun

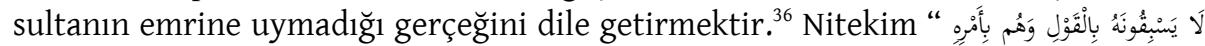
"ِعْمَلُونَ" "Sözle onu geçmezler ve onlar, onun emriyle hareket ederler." 37 ayeti meleklerin Allah'tan önce konuşmadıkları ve emrine göre hareket ettikleri hakikatini ifade etmektedir.

İbn Kuteybe, mecazın yalan olduğunu ve dolayısıyla Kur'ân'da mecazın olmadığını ileri sürenlerin bu tavırlarının cehaletin en kötüsü olduğunu söylemekte ve eğer mecaz yalan olsaydı, cansız varlıklara isnat edilen insanlara ait özelliklerin de batıl olması gerektiğini söylemektedir. Buna göre yeşillik bitti, ağaç uzadı, meyve olgunlaştı ve para (değer anlamında) düştü gibi ifadelerin hepsi yanlış olmuş olur. ${ }^{38}$ Araplar, "بأرض فلان شجر قد صاح" "filan yerde bir ağaç bağırdı" derken bağırmayı ağacın

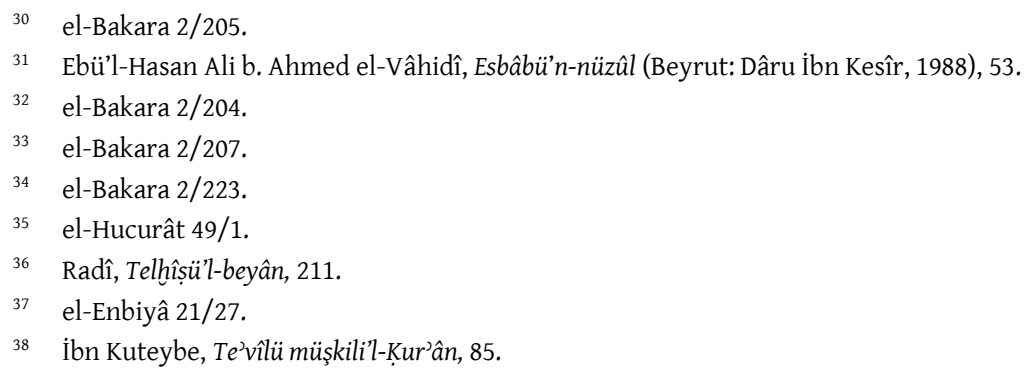


uzaması için, yani ağaç boyuyla görenlerin gözüne iliştiğinde bu ifadeyi kullanırlar. Çünkü bağıran kimse nasıl sesiyle dikkatleri üzerine çekiyorsa uzayan ağaç da boyuyla dikkatleri üzerine çekmektedir. Nitekim Araplar bir ağaç çiçek açtığında " هذا ضحكت "Bu vaat (ümit) veren bir ağaçtır." ve yer yeşillikle kaplandığında "شجر واعد " لخد "Ylلr tebessüm etti." derler. Çünkü yeşillik bollaşıp çiçekler açtı̆̆ında adeta yeryüzü güler. ${ }^{39}$

$$
\text { يريد الرمح صدر ابي براء / ويرغب عن دماء بني عقيل }
$$

"Mızrak Ebû Berrâ'nın göğsünü istiyor / Benî Akîl'in kanından yüz çeviriyor." ${ }^{30}$ şeklindeki şiirde anlaşıldığı gibi edip ve şairlerin de mecazı çok kullanma teamüllerinden dolayı Kur'ân'da "İ̧̧ ciddiye bindiği zaman"41 "Ticaretleri kar etmedi." "G2 "Gömleğinin üstünde yalancı bir kanla geldiler." ${ }^{43}$ ayetlerinde olduğu gibi mecaz çok kullanılmıştır. Zaten belagatte Arap ediplerine meydan okuyan bir kelamın mecazsız olamayacağı malumdur. Nitekim Hatîb el-Kazvînînnin ifade ettiği gibi belagat erbâbının, "şبقeklinde mecazın hakikatten daha beliğ olduğu üzerinde ittifak etmesi bu realiteyi ifade etmektedir. ${ }^{44}$ Bundan dolayı Kur'ân'da mecazı reddedenlerin görüşlerinin isabetli olmadığı söylenebilir. Artı olarak bazı durumlarda Kur'ân'daki mecazların evrensel hakikatlere işaret edilebileceğini bazı durumlarda da mecazî anlamın hakiki anlamı önceleyebileceğini söylemek mümkündür.

\section{Temsilî Anlatım}

Mecazın mürekkeb denilen (yani birçok yön içeren) kısmı temsilî anlatımdır. Temsil, mürekkeb bir ifadenin lâzımî manası kastedilen kelamdır. ${ }^{45}$ Ancak asıl olarak temsil, soyut bir şeyi somuta benzeterek anlatmaktır. Hayalî bir senaryonun sahnede canlandırılmasına da bu ilişkiden dolayı temsil denilmektedir. Kur'ân'da ise temsil, soyut, gaybî durumları algılanan ve müşahede edilebilen şeylere benzeterek anlatmaktır. Cennet, cehennem, şeytan, ödül ve ceza gibi gaybî hakikatlerin bu şekilde temsilî olarak anlatıldığını söyleyebiliriz. Örneğin,

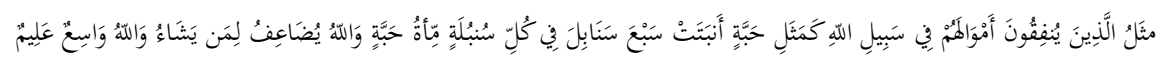

"Mallarını Allah yolunda harcayanların durumu, her bașağında yüz tane olmak üzere yedi başak veren bir tanenin durumu gibidir. Allah dilediğine kat kat verir. Allah(ın lütfu)

\footnotetext{
39 İbn Kuteybe, Te'vîlü müşkili'l-Kur'ân, 86, 88.

40 İbn Kuteybe, Te'vîlü müşkili'l-Ḳur'ân, 86.

41 Muhammed 47/21.

42 el-Bakara 2/16.

43 Yûsuf 12/18.

44 Hatîb el-Kazvînî, el-ị̂âh. 249.

45 Muhammed Aclâ b. Ali el-Fârûkī et-Tehânevî, Keşşâfü ıș̣tlâhâti'l-fünûn (Beyrut: Dârü'l-Kütubi'lİlmiyye, ts.), $1 / 289$.
} 


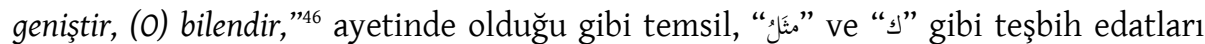
kullanilarak dile getirilir. Bu temsilde soyut olan durum, yani mükâfat somut bir manzaraya benzetilerek anlatılmıştır. Bu tarz ayetler Kur'ân'da hayli fazladır: ${ }^{47}$

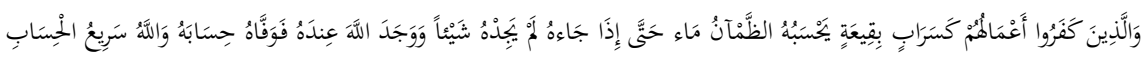

“İkâr edenlerin yapıp ettikleri, susamış kimsenin geniş düzlüklerde görüp su zannettiği serap gibidir; sonunda gelip ona ulaşınca orada bir şey bulamaz, ama Allah'l yanında bulur, O da eksiksiz olarak hesabinı görüverir. Allah'ın hesabı pek çabuktur."48 Bu ayet iman olmadığ1 takdirde amellerin boşa gideceğine dair bir temsildir. Allah'1 yanında görmesi, Allah'ın vaadini bulması, yani ceza görmesi anlamındadır. ${ }^{49}$ Nasıl serap gören kişi onu gerçek bir şey zannederken bir hayalden ibaret olduğunu işin sonunda anliyorsa, inkâr edenlerin de durumu böyledir. Zira onlar da amellerinin karşılığında hiçbir şeyi elde edemeyeceklerini işin sonunda anlayacaklardır. Bu temsille, inanç olmadığı takdirde insanın amel ve umutlarının nasıl boşa çıkacağı ve bunların karşılığını alamayacağı ortaya konulmuştur.

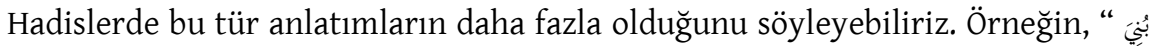

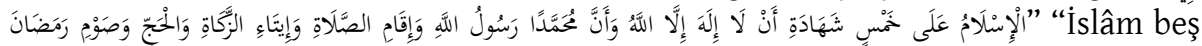
(rükün) üzerine bina edilmiştir: Allah'tan başka ilah olmadı̆̆ına ve Muhammed'in onun elçisi olduğuna inanmak, namaz kılmak, zekât vermek, haccetmek ve Ramazan'da oruç tutmak." ${ }^{50}$ hadisinde İslâm bir binaya benzetilmektedir. Nasıl binanın ayakta durması için kolonlar şartsa, İslâm'ın varlığı için de dile getirilen beş esas şarttır. Böyle bir temsille İslâm'ın şartlarının önemi ortaya konulmuştur.

Benzer örneği, “'اق طعم الإيمان من رضى بالله رباً وبالإسلام ديناً وبمحمد رسولا" "Rab olarak Allah'tan, din olarak İslâm'dan, resul olarak da Muhammed'den razı olan imanın tadını almıştır." ${ }^{11}$ hadisinde de görmek mümkündür. Hadiste imanın sağladığı içsel huzur yemekten alınan tada benzetilmiştir. Hâlbuki iç huzur maddî olan bir lezzete benzemez. Ancak böylesine bir temsilî anlatımla dinin metafizik gerçekleri anlaşılır hale gelmektedir. Çünkü din, fizik ötesi bir boyuttan bahsettiğinden ancak temsilî anla-

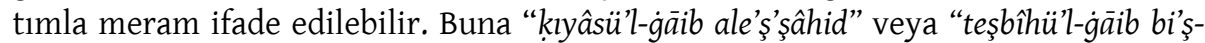
şâhid" yani bilinmeyen bir dünyayı bilinen dünyanın formatlarıyla anlatmak veya bilinmeyen bir dünyayı bilinen dünyanın olgularına benzeterek anlatmak denilmektedir.

Bazı psikolojik durumlar da genellikle bu yolla anlatılmaktadır. Allah Resûlü’nün (s.a.v.) “.....ِ “Cimri ile infak edenin

\footnotetext{
46 el-Bakara 2/261.

47 Âl-i İmrân 3/117; İbrâhîm 14/18.

48 en-Nûr 24/39.

49 Radî, Telhîsüül-beyân, 144.

50 Buhârî, “İmân”, 2 (8).

51 Müslim, “İmân”, 56 (34).
} 
hali üzerinde demirden bir cübbe bulunan adamın hali gibidir..." ${ }^{52}$ şeklinde cimri ve cömerdin halini üzerinde demirden bir cübbe taşıyan adama benzetmesi bu kabil bir anlatımdır. Bu hadiste cimrinin ruhsal sıkıntısı ve cömertin içsel huzuru kişinin üzerindeki demirden cübbenin daralması ve bollaşmasıyla ifade edilmiştir. Bu bağlamda birçok dikkat çekici hadisin olduğunu söylemek mümkündür. ${ }^{53}$

Kur'ân'da bazı temsillerde teşbih edatları kullanılmamaktadır. Bunları "kâmin (gizli)" temsil olarak isimlendirmek lazımdır.

Kur'ân'ın kâmin temsillerinin en güzel örneklerden biri, insan bencilliğinin sert bir yokuşa benzetilmesidir:

"Fakat o, sarp yokuşa atılmad. Sarp yokuşun ne olduğunu sen nereden bileceksin? Bir boynu (kölelik zincirinden) çözmek yahut açllk gününde doyurmaktır: Akraba olan yetimi yahut hiçbir şeyi olmayan yoksulu. Sonra inanip birbirlerine sabır tavsiye eden ve merhamet tavsiye edenlerden olmaktır. ${ }^{\prime 4} 4$ ayetinde nasil insan sarp bir yokuşu hızla tırmanırken nefesi kesiliyorsa cimriliğin de insanın nefesini kesen katı ve yenilmesi zor bir zaaf olduğunun temsil yoluyla anlatıldığını söyleyebiliriz. Aynı șekilde,

"Körle, gören bir olmaz. Karanllkla, aydınlk da bir olmaz. Gölge ile hararet de bir olmaz..." ${ }^{55}$ ayetinde kâfir ile mümin arasındaki fark temsilî olarak kör ile görene; açk ve aşikâr olan hak, aydınlığa; batıl da, karanlığa; gölge ile sıcaklık, ölü ile diriye benzetiliyor. Demek ki kör Allah Resûlüne (s.a.v.) iman etmeyen, onun getirdiği hakikate gönül gözü kapalı olan kâfiri; gören de iman eden, onun getirdiği hidayet nuruna karşı gönül gözü açık olan mümini temsil etmektedir. Gölge ve sıcaklık da cennet ve cehennemi; diri ve ölü de mümin ve kâfiri temsil etmektedir. ${ }^{56}$

"Onlardan gücünün yettiğini sesinle yerinden oynat; atlların ve yayalarıla onların üzerine yaygarayı bas; mallarda ve evlatlarda onlara ortak ol (bunları haram yoldan kazanmaya sevk et); onlara (çeşitli) vaatler yap -gerçi şeytan onlara aldatmadan başka bir şey

52 Buhârî, "Zekât" 28 (1443); Ebû Abdullah Ahmed b. Muhammed b. Hanbel eş-Şeybânî, el-Müsned (İstanbul: Çağrı Yayınları, 1992), 2/256.

53 "Kötülük yaptıktan sonra iyilik yapanın meseli, üzerinde boğazına kadar uzanan ve onu boğmaya çalışan dar bir zırh giyen kişi gibidir..." Ebü'l-Kāsım Süleyman b. Ahmed b. Eyyûb et-Taberânî, el-Mu'cemü'l-kebîr (Mektebü'l-Ulûm ve'l-Hikem, 1983),

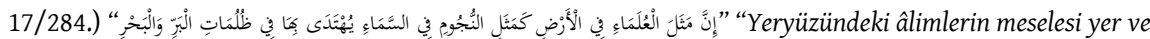
deniz karanliğında kendileriyle yol bulunan gökteki yıldızlar gibidir.” (Ahmed b. Hanbel, Müsned, 3/157) "Allah'in benimle birlikte gönderdiği hidayet ve ilmin meseli gökten yağan ve yerden temiz (bereketli) bir toprağın kabul ettiği bol yağmur gibidir..." (Buhârî, "ilim” 20 (79) şeklinde birçok hadis bu tarz temsilî anlatımı içermektedir.

54 el-Beled 90/11-17.

55 el-Fâtır 35/19-21.

56 Nâsıruddîn Ebû Saîd Abdullah b. Ömer b. Muhammed el-Beydâvî, Envâru't-tenzîl ve esrâru't-te'vîl (Beyrut: Dâru'r-Reşîd, 2000), 3/120. 
vadetmez." ${ }^{57}$ ayetindeki hitap şeytanadır. Bazı ulemaya göre ayette atlılar ve yayalar, insan ve cinlerden şeytana itaat edip ona yardımcı olan ve Allah'a isyan eden herkestir. ${ }^{58}$ İbn Abbas'a göre ise Allah'a isyan etme ve günah işleme hususunda çaba sarf eden her süvari ve yaya, şeytanın süvari ve yayası sayılır. ${ }^{59}$ Ayette insanları ses ile yerinden oynatmak, oyun ve çalgı sesleriyle onları iğva etmektir. Allah'a isyanda olan her binekli şeytanın bir atlısı, piyade de onun askeridir. ${ }^{60}$ Buradan hareketle ayetteki hitabın şeytan ve yandaşlarına olduğunu söyleyebiliriz. Ancak Şah Veliyullah ed-Dihlevî̀ye (ö. 1176/1762) göre şeytan, avenesini çağırıp “şu taraftan girin, şu taraftan baskın yapın” diye seslenip yol kesen eşkıya reisine benzetilmiştir. Dolay1sıyla hitap şeytana aittir. Arapların şiir ve hutbelerinde bu tarz anlatımın geniş yer tutması bu hususu göstermektedir. ${ }^{61}$ Malda ortak olmak, onu haram yollarla kazanmayı, evlatta ortak olmak ise nesli zina gibi gayri meşru yollarla edinmeyi ifade ettiği söylenebilir.

Kudsî bir hadiste Allah'ın:

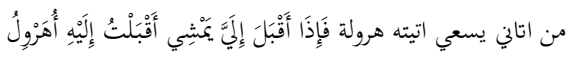

“(Bir kulum) bana yürüyerek gelse ben ona koşarak giderim." ${ }^{62}$ demesi kâmin temsilîn güzel örneklerinden birisidir. Çünkü gerçekte Allah koşmaz. Hadisin, insanların anlamalarını sağlamak için gaybî varlık olan Allah'ın, bir kulunun imana yönelmesinden duyduğu sevincini temsilî bir anlatımla, yani insan biçimci bir davranışla anlattığı söylenebilir. Nitekim şu ayetlerde benzeri bir temsil vardır:

“Hep birlikte Allah'in habline (ipine) sımsıkı sarılın. Parçalanıp bölünmeyin. Allah'ın size olan nimetini hatırlayın. Hani sizler birbirinize düşmanlar idiniz de 0, kalplerinizi birleștirmişti. İşte O'nun bu nimeti sayesinde kardeşler olmuştunuz. Yine siz, bir ateş çukurunun tam kenarında idiniz de 0 sizi oradan kurtarmıştı. İşte Allah size ayetlerini böyle apaçı bildiriyor ki doğru yola eresiniz."

Şerif er-Radî̀ye (ö. 406/1015) göre Arap dilinde "Habl", verilen söze de denilir. Sözün habl olarak isimlendirilmesi, sel ve çukur gibi korkulacak tehlikeli bir pozisyona düşen kişinin ipe sarılarak kurtulup emniyete kavuşmasına benzemesinden dolayıdır. ${ }^{64}$ Çünkü ayette "Allah'ın ipi" ifadesinin Allah'ın emir ve nehiylerini beyan eden esaslar olduğu açıktır. Bu esaslara riayet etmenin "Allah'ın ipine sımsıkı tutunmak” olarak ifade edilmesinde güçlü bir benzetme vardır. Çünkü kuyuya düşen bir

\footnotetext{
57 el-İsrâ 17/64.

58 Ebü'l-Fidâ İmâdüddîn İbn Kesîr, Tefsîru'l-Kur'âni'l-'aẓim (Kâhire: Mektebetü Evlâdi'ş-Şeyhi li't-Türâs, 2000), 5/93-94.

59 Fahreddin er-Râzî, et-Tefsîru'l-kebîr (Beyrut: Dâru İhyâ’i't-Türâsi'l-Arabî, 1998), 14/529.

60 Radî, Telhîșül-beyân, 109.

61 Şah Veliyyullah ed-Dihlevî, el-Fevzü'l-kebîr fì ușûli't-tefsîr (Dımeşk: Dâru'l-Gavsânî, 2008), 158.

62 Buhârî, “Tevhid” 15 (6970); Müslim, “Zikr ve Dua” 1 (2675).

63 Âl-i İmrân 3/103.

64 Radî, Telhîșïll-beyân, 26.
} 
insan kurtulabilmek için kendisine uzatılan ipe sıkı bir şekilde tutunur. İnsan için ipe tutunmak ne kadar önemliyse; kişinin dünya ve ahiret saadetine erişmesi için Allah'ın emir ve nehiylerine sımsıkı tutunması da o derece önemlidir. Aynı şekilde,

"Biz onların boyunlarına halkalar geçirdik. Çenelere kadar dayanan o halkalar yüzünden kafaları kalkıktır. Önlerinden bir set ve arkalarından bir set çektik de onları kapattık; artık görmezler" ${ }^{\prime 65}$ ayetinde de Allah'a inanmayanların onun ayetlerini düşünmemeleri ve ondan yüz çevirmeleri, iki eli boyuna kelepçelenerek hareket alanı kalmayan veya her tarafına set çekilmiş artık hiçbir yeri göremeyen kimselere benzetilmiştir. ${ }^{66}$ Muhammed Hamdi Yazır (ö. 1942), aslında bu benzetmenin, batıl inançlar, çirkin alışkanlıklar, kötü huylar, taklit, taassup, heva gibi küfrü ve kötülüğü hoş gösterip imandan kaçındıran kötü melekelere ve sıfatlara nefislerini alıştıra alıştıra değişmez hale getiren kişiler için yapıldığını söylemektedir. ${ }^{67}$ Mevdudî de aynı paralelde, "Boyunlarına halkalar geçirdik", ifadesinin kâfirlerin hakkı kabule engel olan inatların1, "Çenelere kadar dayanan o halkalar yüzünden kafaları kalkıktı" ifadesi de onların kibrine yapılmış bir temsil olduğunu söylemektedir. Bundan dolayı temsil, bu gibi kişilerin ne kadar kanıt getirilse de hakikati göremedikleri ve açık delilleri kabul etmediklerini, "Önlerinden bir set ve arkalarından bir set çektik" ifadesinin de ne geçmişten ders aldıklarını, ne de istikballerini düşündüklerini ifade etmektedir. ${ }^{68}$

"Ey insanlar, yeryüzünde bulunan helal ve temiz şeylerden yiyin, şeytanın adımların izlemeyin; çünkü o, sizin apaçık düşmanınızdır." ${ }^{169}$ Ayette Allah'ın helal kıldığını haram kılmak şeytanı adım adım takip etmek, yani onu örnek almaktır. Ayetin sebeb-i nüzulü olarak şu olay anlatılır: Cu'fî kabilesi hayvan kalbinin helal olmasına rağmen haram kabul ediyordu. Bu kabileden iki kardeş olan Kays b. Seleme b. Şurahil ve Seleme b. Yezîd Müslüman olduklarında Allah Resûlü (s.a.v.) onlara "Bana ulaştı̆̆ı kadarıyla siz hayvan kalbini yemiyorsunuz." dedi. Onlar da "Evet yemiyoruz." dediler. Bunun üzerine Allah Resûlü, "Sizin İslâm'ınız ancak kalp yemekle tam olur." dedi. Sonra bir kalp kızartarak onlara yedirtti. ${ }^{70} \mathrm{O}$ halde ayet şeytanı örnek almayı temsilî bir yolla anlatmaktadır. Çünkü birisini davranışlarıyla taklit eden, onu adım adım takip eder ve böyle bir kimse takip ettiğini örnek alır. $O$ halde ona ittiba etmemek de aksi davranmakla mümkündür.

Kur'ân, psikolojik durumları da somut olgulara benzeterek temsilî yolla anlatmaktadır. Tereddütlü bir kimsenin, "Bir adımını ileri bir adımını geri atıyorsun" şeklinde nitelenmesi gibi. ${ }^{71}$ Kur'ân münafikların hallerini, "Arada yalpalayıp dururlar.

\footnotetext{
65 Yâsîn 36/8-9.

66 Dihlevî, el-Fevzü'l-kebîr, 160.

67 Muhammed Hamdi Yazır, Hak Dini Kur'ân Dili (İstanbul: Eser Neşriyat, 1978), 4/4011.

68 Ebü'l-A'lâ Mevdûdî, Tefhîmü'l-Kur'ân, çev. Hamdi Aktaş (İstanbul: İnsan Yayınları, 1986), 4/513.

69 el-Bakara 2/168.

70 Ebû Abdullah Muhammed b. Sa`d b. Menî‘, eț-Ṭabâkātü’l-kübrâ (Beyrut: Dâru Sâdır, ts.), 1/324; Ebü’lFida İmâdüddîn İbn Kesîr, el-Bidâye ve'n-nihâye (Beyrut: Hecr, ts.), 5/109.

71 Hatîb el-Kazvînî, el-ị̂âh, 231.
} 
Ne bunlara (müminlere bağlanırlar), ne de onlara (kâfirlere bağlanırlar. Allah'ın şaşırttığı kimseye bir (çıkar) yol bulamazsın!"72 şeklinde nitelemesi temsilî bir anlatım olup bu yolla onların menfaat eksenli kararsızlıkları somutlaştırılmaktadır.

$\mathrm{Bu}$ örneklerden anlaşıldığı gibi Kur'ân çok yoğun bir şekilde temsilî anlatımı kullanmıştır. “Andolsun biz, Kur'ân'ı öğüt almak için kolaylaştırdık. Öğüt alan yok mudur?"73 ayetinden de büyük oranda bu anlatım tarzına ve bunun anlamdaki işlevselliğine vurgu yapıldığı, bunun edebî yorum olmasına rağmen ümmîlerin bile bu yolla Kur'ân'ın yüksek hakikatlerini algılayabildikleri söylenebilir.

Bu bağlamda Kur'ân'da irdelenmesi gereken iki konu vardır.

\subsection{Cansız Varlıklara Bilinç ve Konuşma Özelliğinin Verilmesi}

Kur'ân'da birçok ayette cansız varlıklara algı verilmekte, zaman zaman da onlarla konuşulmaktadır. Zemahşerî bunun bir temsilî anlatım olduğunu söylemekte ve cansız varlıklarla konuşmanın Arap dilinde oldukça fazla bulunduğunu, Kur'ân'da Araplar arasında cari olan bu üsluba uyduğunu söylemektedir. 0 , yağa nereye gidiyorsun denildiğinde, "Ben eğrilikleri düzeltmeye gidiyorum" demesi gibi, nice hayvan ve cansızların dilinden sözler aktarıldığını ifade etmektedir. ${ }^{74}$ Bunu esas alırsak, "Biz emaneti, göklere, yere ve dağlara sunduk; onu yüklenmekten kaçındılar, on(un sorumluluğun)dan korktular; onu insan yüklendi; doğrusu o, çok zalim, çok cahildir."75 ayetinin bir temsilî anlatım olduğu ifade edilebilir. Nitekim buradaki emaneti hakiki anlamda gören müfessirler olsa da çoğu bunun, emanetin azametini beyan etme konusunda bir temsilî anlatım olduğunu söylemektedir. ${ }^{76}$

Aynı durum "Daha sonra (Allah) gök ile yere buyurdu: 'Her ikiniz de ister istemez gelin' dedi. Onlar da 'isteyerek geldik' dediler." istemez gelin" ifadesinden maksat gök ve yerin oluşumundan kinaye olup "varlık sahnesine çıkın" anlamındadır. Bu komuta gök ve yerin "isteyerek geldik" demeleri ise Allah'ın emrine uygun fitrî oluşum misakını ifade eder. Kur'ân'ın, beşerî teamülleri esas alarak bize hitap ettiğini göz önüne aldığımızda bu temsilde komutanın askerlerini bir emirle toplaması gibi Allah'ın yeri göğü kolaylıkla, yarattığı inceliği vardır. Ancak bu şekilde yere göğe hitapta bir heybet de vardır. Nûh tufânından bahseden "Ey yer, suyunu yut ve ey gök (suyunu) tut!' "78 şeklindeki ifadede de bunu görmek mümkündür. İbn Atiyye, ayette fiilin mef'ûle isnad edilmesinin ta'zîm ve

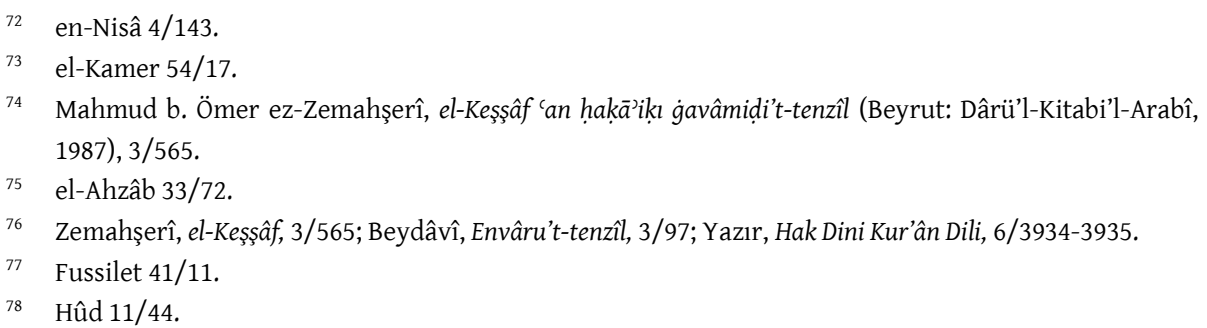


büyüklük için etkileyici bir üslup olduğunu söyler. ${ }^{79}$ Nitekim İbnü'l-Mukaffa (ö. 142/759) Kur'ân benzeri bir söz söylemeye giriştiğinde bir çocuğun bu ayeti okuduğunu işitince bundan etkilenerek yerlere, göklere sözünü dinlettiren bir otoritenin kelamına nazire yapılamayacağını ima ederek, "İşte bu kendisine benzer bir söz getirileyemen Allah kelamıdır." diyerek müsvedelerini yırtmıştır. ${ }^{80}$

O halde "Her ikiniz de ister istemez gelin" ifadesi, "Ey gök! Güneşini, ayını çıkar. Ey yer! Nehirlerini fışkırt, meyvelerini çıkar"; onların "isteyerek geldik" demeleri de "dilediğin gibi olduk" ${ }^{\prime 1}$ şeklinde bir tekvinî emri ve oluşumu ifade eder. Yani ayetteki emir oluşuma yönelen ilahi iradeyi, yerin gögün itaati de bu iradeye uygun oluşumu ifade eden bir temsilî anlatım olmuş olur.

\subsection{Hayvanlarla Konuşma}

Kur'ân'da bazı ayetlerde hayvanlarla konuşulduğu görülmektedir. Örneğin, "Karinca vadisine geldikleri zaman bir karınca: 'Ey karıncalar dedi, yuvalarınza girin ki Süleyman ve orduları farkında olmayarak sizi ezmesinler. ${ }^{" 22}$ şeklinde karınca konuşması ve "Ben senin bilmediğin bir şeyi öğrendim. Sana Sebe'den sağlam haberler getirdim..." ${ }^{33}$ şeklinde hüdhüdün $\mathrm{Hz}$. Süleyman ile konuşması bu tarzdır. Görüldüğü gibi bu ayetlerde hayvanlara insan gibi bilinç ve konuşma yeteneği verilmektedir. Aşağıda açıklayacağımız gibi müfessirlerden bazıları bunun temsilî bir anlatım olduğunu söylemektedir.

Aslında bu ayetlerle ilgili iki görüş vardır:

1. Olay gerçektir. Âlûsî karıncanın konuşmasıyla ilgili olarak bu seçenekte ısrar etmekte ve şöyle demektedir: Temsilî anlatımı yapmaya sevk edecek zorunlu bir durum yoktur. Karıncanın durumunu araştıran birisi onun akıllı bir nefse sahip olduğunu uzak bir ihtimal olarak görmez. Karınca yazın topladığını kışın yemek için biriktirir ve tahılları rutubetten dolayı çimlenmesin diye ikiye ayırır. Kişniş ve mercimeği ise dört parçaya ayırır. Çünkü bunlar yarıya parçalansa çimlenir. İşte bu ve bunun gibi şeyler sebep-sonuç alakasını kuran bir ilmi ve düşünen bir nefsi gerektirir ${ }^{84}$ Nitekim Allah Resûlü'nün de hayvanlarla konuştuğuna dair bazı sahih hadisler vardır. ${ }^{85}$ Günümüzde de hayvanları ve onların rutin faaliyetlerini gözlemleyen incelemeler de hayvanların kendi aralarında seslerle mükemmel bir iletişim kurduklarını ortaya koymuştur. Nihayet karınca yaşamlarını gözlemleyen araştır-

79 Ebû Muhammed Abdülhak İbn Atiyye, el-Muharrerü'l-vecîz (Devha: Vezâretü'l-Evkâf ve Şuûni'lİslamiyye, 2008), 4/584.

80 Ignaz Goldziher, Muslim Studies (London: George Allen and Unwin, 1971), 363.

81 Zeyd b. Ali b. Hüseyin, Garîbü'l-Ḳur'ân (İran: el-Mektebetü'l-I'lâmi'l-İslâmî, 1418), 356.

82 en-Neml 27/18.

83 en-Neml 27/22.

84 Ebü'l-Fadl Şihâbüddîn el-Âlûsî, Rûhu'l-me'ânî (Beyrut: Dârü'l-Fikr, 1987), 19/176.

85 Ebû İsa Muhammed b. Sevre et-Tirmizî, Sünen (Riyâd: Beytü-l-Efkâr, ts.), "Menâkıb” 3627-3628. 
malar karıncaların yer altında insan medeniyetine benzer şekilde ev, sokak ve çalışma alanlarını içerir büyük yaşam birimleri kurdukları ve bu birimlerde çok sistemli ve yoğun bir faaliyet ortaya koyduklarını tespit etmiştir.

2. Beydavî (ö. 685/1286) gibi bazı ulema ise bunun bir temsilî anlatım olabileceğini söylemektedir. Şöyle ki, ayette bir karınca Hz. Süleyman'ın ordusunun vadiye yöneldiğini gördüğünde ezilme korkusuyla kaçmış, diğerleri de ona tabi olmuştur; yanında bulunan gruba da kaçmaları için (kendi iletişimleriyle) seslenmiş ve onlar da ona tabi olarak kaçmışlardır. Bu kaçış temsilî olarak akıllıların kaçışına, kaçarken de birbirlerine tavsiyelerde bulunmalarına benzetilerek aktarılmıştır. ${ }^{86}$ Nitekim İbn Kuteybe, nüzûl ortamında Arap dilinde çok yaygın bir şekilde cansız varlıkların intak ve hayvanların fablla konuşturulduğunu söylemesi ${ }^{87}$ bu seçeneği desteklemektedir.

Ayetteki konuşmayı bu şekilde temsilî bir anlatım kabul edersek aynı sûrede hüdhüdün hikâyesinde de tersine bir temsil olduğunu söylemek mümkündür. Şöyle ki eskiden uzaktan haberleşme vasıtası olarak kuşlar kullanılırdı. Kur'ân'ın, Süleyman ve Belkıs hikâyesinin anlatımı esnasında bir muhaberat elemanı gibi hüdhüdden haber nakletmesi ${ }^{88}$ bunu çağrıştırmaktadır. Büyük ihtimalle Belkıs ve konseyinin hallerini rapor eden bir muhaberât elemanı raporu kuş vasıtasıyla göndermiş ancak raporun ifşası âdet ve tağlîb yoluyla mektubu getiren kuşun diliyle ifade (intak) edilmiştir. Bunu esas aldığımızda hüdhüdün konuşması hayvanlara şahsiyet vererek konuşturma, onların diliyle ögüt ve ders verme şeklindeki edebiyatta kendisine fabl denilen edebî bir anlatım tarzı olur. Nitekim Kur'ân'ın edebî bir metin olduğu unutulmamalıdır. Ancak bu tarz yorum "And olsun biz, Dâvûd'a ve Süleyman'a bir ilim verdik de onlar: 'Bizi inanan kullarından birçoğuna üstün kılan Allah'a hamdolsun.' dediler. Süleyman, Dâvûd'a mirasçı oldu. Dedi ki: 'Ey insanlar, bize kuşların dili öğretildi ve bize her şeyden (bolca) bir pay verildi. İşte bu açık bir lütuftur." ${ }^{89}$ ayetleriyle çelişmektedir. Çünkü bu ayette diğer insanlara verilmeyen bir ilmin Hz. Dâvûd ve Hz. Süleyman'a verildiğinden bahsedilmektedir. Bu da kuşları anlama konusunda Süleyman peygamberde artı bir yetenek tekâmülü geliştiğini ortaya koymaktadır. Dihlevî bu yeteneğin kuşları anlamaya dair olduğunu söylemektedir. $\mathrm{O}$, kuş ve hayvanların ihtiyaç anında kendilerine ilham edilen doğal ilimleri olduğunu ifade etmekte ve şöyle söylemektedir: "Olabilir ki Allah, bir sıkıntıdan kurtulmak veya bir yarara ulaşmak için onlara yararlı bir durum irade edebilir. Buna bağlı olarak onların kalbine bir şey ilham eder. Allah, Hüdhüd olayı gibi bir kuş vasıtasıyla bir kula bir şey öğretebilir. Öfke, korku, şehvet ve açlık gibi kuşlarda meydana gelen hallere delalet eden bazı sesler vardır. Allah Süleyman peygambere bu ilmin birçoğunu öğretmiş olabilir. Nitekim Allah bazen kabiliyetli insanlara da bu tarz ilimden bazı şeyler

\footnotetext{
86 Beydavî, Envâru't-Tenzîl, 2/ 563; Âlûsî, Rûhu'l-me`ânî, 19/176.

87 İbn Kuteybe, Te'vîlü müşkili'l-Kurưân, 70-73; Zemahşerî, el-Keşşâf, $3 / 565$.

88 en-Neml 27/28.

89 en-Neml 27/15-16.
} 
verebilir. Bu gibi ilim nadirattan olduğundan bir kural altına girmiyor." demektedir. ${ }^{90}$ Zaten "Mantıku't-Tayr" ifadesini nutuk(konuşma)dan ziyade iniltinin rahatsızlığa delalet etmesi gibi bir anlama delalet eden ses şeklinde tefsir etmek en uygun yorumdur. Nitekim Râğıb el-İsfehânî kuşdilini anlayan Süleyman'a göre kuş sesleri nutuktur. Çünkü bir kimse bir şeyi anlasa o şey suskun olsa da, ona göre nâtıktır, der. ${ }^{91} \mathrm{Bu}$ aynen şuna benzer: Narkotikte kullanılan köpeklerin esrarı keşfedip havlaması esnasında uzman birisinin, "köpek esrarın burada olduğunu söylüyor" demesi gibi bir kullanım olduğu, buna göre hayvanların dilinden anlayan bir ferasetin Hz. Süleyman'da inkişaf ettiğine delalet ettiği söylenebilir. Bu esas alındığında hayvanların konuşması figüratif bir konuşma olmaktadır. $O$ halde hüdhüdün konuşması, Süleyman peygamberin ordusunda kuşların da içinde kullanıldığı muhaberâtını, cinler de ordudaki manevî güçlerin de içinde olduğu sanat erbaplarını ifade ettiğini söyleyebiliriz.

\section{Müteşâbih ve İlgili Bazı Ayetleri Anlama Metodolojisi}

Müteşâbihi ulemadan bazıları, özelde şeytanın vahye sokmaya çalıştığı vesvese olarak $^{92}$ veya selefin 1 stılahında tercih edici bir muarız nedeniyle zahiri terk edilendir ${ }^{93}$ şeklinde tanımlarlar. Onlar, bunu esas alarak mensûhu müteşâbih kategorisine soksalar da, genel kabul anlam açısından ikilem içinde kalınan ya da lafzı altında çeşitli anlamların gizlendiği ayetlerdir. Nitekim müteşâbih lafzındaki müşâreketin de bu durumu ima ettiği söylenebilir.

Erken dönem tefsircilerinden Taberî (ö. 310/923) müteşâbihi, okunuşta aynı, anlamda ise farkl1 $;{ }^{94}$ Ebû Mansûr el-Mâtüridî (ö. 333-944) ise; dillerinin farklllı̆̆ı nedeniyle insanlara karışık görünen ve içinde ihtilaf edilen ya da bâtınının işaret ettiğine zahirinin etmediği (yani zahirinin murad-ı ilahiye uygun olmadığı) ifadeler şeklinde yorumlamıştır. ${ }^{95} \mathrm{Bu}$ bağlamda en esaslı ve kapsamlı tanımı İbn Teymiyye (ö. 728/1328) yapar.

İbn Teymiyye müteşâbihi, iki anlama ihtimali olan, muhkemi ise farklı şekillerde anlaşılmaya kapalı bir kelam şeklinde tanımlar. ${ }^{96}$ Bundan dolayı nâsih tanındığında (yani şeytanın vahye soktuğu devre dışı bırakıldığında) muhkem de tanınmış

90 Şah Veliyyüllâh ed-Dihlevî, Te'vîlâtü'l-ehâdîs (Pakistân: Akâdemiyyetü Şah Veliyullah ed-Dihlevî, 1966), 64.

91 Ebü'l-Kāsım Hüseyin b. Muhammed er-Râgıb el-İsfahânî, el-Müfredât fí garî̉bi'l-Ḳur'ân (Beyrut: Dârü'lMacrife, ts.), 498.

92 el-Hac 22/52. bk. Takıyyüddîn Ebü'l-Abbas Ahmed b. Abdülhalim İbn Teymiyye, el-iklill fill-müteşâbih ve te'vîl ('̇skenderiyye: Dârü'l-İmân, 2002), 8.

93 Âmmın tahsisi ve mutlakın takyidi gibi; bk. İbn Teymiyye, el-ikklîl, 9.

94 Ebû Ca'fer et-Taberî, Câmi' u'l-beyân 'an te'vîli âyi'l-Kur'ân (Kâhire: Hecr ts.), 5/192.

95 Ebû Mansûr Muhammed el-Mâtürîlî, Te'vîlâtü'l-Kur'ân (ìstanbul: Dâru'l-Mîzân, 2005), 2/243.

96 İbn Teymiyye, el-ikkill, 10. 
olur. ${ }^{97} \mathrm{Bu}$ anlayış esas alındığında mensûh, müteşâbihtir demek doğru bir ifade olur. İbn Teymiyye'nin bu tanımından onun, muhkemi nâsih ve müteşâbihi mensûh kabul eden Katâde (ö. 117/735) ve te'vîlinde icma edileni muhkem, ihtilaf edileni de müteşâbih kabul eden Esam'ın (ö. 200/816) görüşünü̈ tercih ettiği anlaşılmaktadır. Bu görüşün, aynı konuda zıtlaştıkları için hangi ayetin geçerli olduğuna karar vermede ya da munsûhu devre dışı bırakmada nâsih ile birlikte nüzûl zamanlarının tespitine kadar ikilem yaratması mantığına müstenit olduğunu söylemek mümkündür.

Müteşâbihin en hassas konusu sıfatların te'vîli meselesidir. Selef sıfatları te'vîl etmeden kabul etmiştir. Ümmü Seleme'ye istivadan sorulunca o "İstiva malumdur, keyfiyeti meçhuldür. Ona iman vaciptir. Ondan sual etmek bid'attır." demiştir. ${ }^{99}$ İmam Mâlik'e (ö. 179/795) de istiva sorulunca o da Ümmü Seleme'nin bu cevabını vermiş ve ilave olarak "Kim bana bu soruyu tekrar sorarsa boynunu vururum." demiştir. Süfyân es-Sevrî (ö. 161/778) ve Evzâî (ö. 157/774) de müteşâbihlerle ilgili soru soranlara benzer cevap ve reaksiyonlar ortaya koymuşlardır. ${ }^{100}$ Aslında Kur'ân'ın Allah'ın sıfatları hakkındaki nitelemeleri beşer merkezli olup bununla lafız ötesi hakikatleri, yani lahuti olanı beşerî olanla dile getirdiğini, bu konudaki müteşâbihlerin de bir nevi temsilî anlatım olduğunu söyleyebiliriz. Nitekim istivayı "Allah'ın, arşın mahlûkatına yöneldi, onları kastetti, bunu da istiva olarak ifade etti." şeklinde yorumlayan Ferrâ (ö. 458/1066), Eş̧arî (ö. 324/935-36) ve meânî ehlinin yorumunun doğruluğu üzerinde ulemanın ittifak etmesi, bu yorumun hem tactîl hem de tecsîmden uzak olduğunu söylemeleri bu görüşü desteklemektedir. ${ }^{101} \mathrm{O}$ halde bu bağlamda bütün problemin lahuti olanı beşerî olanla anlamaya çalışmamızdan, bunun bir temsilî anlatım olduğunu göz ardı etmemizden kaynaklandığını söyleyebiliriz.

Sıfatları te'vîl etmenin caiz olmadığının en şiddetli savunucusu İbn Teymiyye olup bunların te'vîlini bir nevi tahrif olarak gördüğünden Ehl-i sünneti ve kelamc1lardan bazılarını tekfir etmiştir. ${ }^{102}$ Hâlbuki Ehl-i sünnet'in birçoğu Allah'ın kendisine nispet ettiği organları, uzuv olmaktan ziyade birer sıfat olarak görmesine ve Selef gibi bunlarda tevakkuf etmesine rağmen İbn Teymiyye ve onun yolunda yürüyenler tarafından ithamlardan kurtulamamıştır. İbn Teymiyye'nin yolunda yürüdüğ̈̈ Selef müteşâbihlerle ilgili yorum yapmaktan hassasiyetle uzak durmuş, bilgisini Allah'a havale etmişlerdir. Bu bağlamda İbn Kudâme el-Makdisî (ö. 620/1223) Selef in mezhebinin, Allah'ın Kur'ân'da ve Resulünün dilinde kendisini nitelediği sıfat ve isimlerine herhangi bir ekleme ve eksiltme yapmaksızın, sınırlarını aşma-

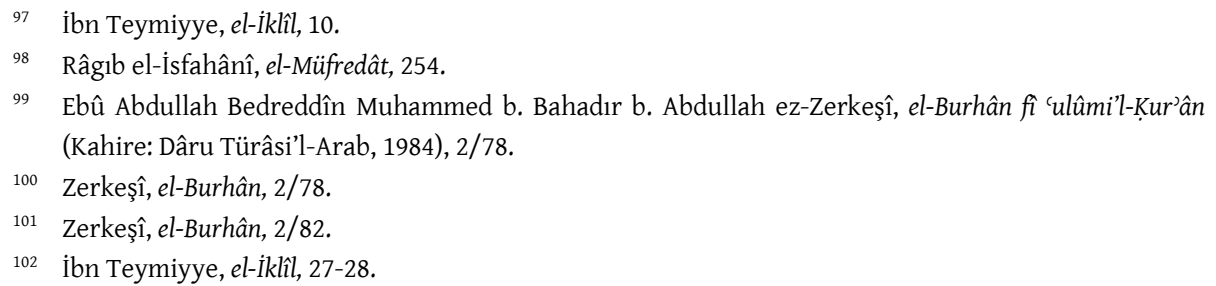


dan, tefsir ve te'vîl etmeden, mahlûkatın sıfatlarına benzetmeden nasıl gelmişse öyle aktararak, ilmini Allah'a havale etmek olduğunu ifade eder. ${ }^{103}$ Halef ise dil ve naslardan deliller getirerek müteşâbihi te'vîl etme yolunu tutmuştur. İbn Teymiyye, "Arşür'-Rahmân" adlı eserinde arşın yedi göğün ötesinde olması, Firdevs cennetinin arşın altında olması, ashabtan bazılarının ölümünde arşın titremesi gibi nitelemeleri esas alarak te'vîlcileri şiddetli tenkide tabi tutmaktadır. ${ }^{104}$ ìbn Teymiyye'nin yolunda yürüyen İbn Kayyım el-Cevziyye (ö. 750-1351), Kur'ân'da Allah'ın birçok ayette kendini bazı sıfatlarla niteledirdiğini, bunları zahirinin hilafına te'vîl edip, mecaza hamledenleri inat ve küfür üzerine yürümekle itham etmiștir. ${ }^{105}$

Muhyiddin İbnü'l-Arabî̀nin (ö. 638/1240) Kur'ân'da Allah'a nispet edilen uzuvların bir temsilî anlatım olduğunu ve "Hiçbir şeyin kendisine benzemediği"106 Allah'ın anlaşılması, kalplerin ünsiyetini sağlamaya yönelik insan-biçimci bir anlatım olduğunu ifade etmesinin ${ }^{107}$ son zamanlarda fazlaca taraftar bulduğunu söylemek mümkündür. Ancak bu görüşün Süyûtî (ö. 911/1505) tarafından el-ítkān'da yanlışlıkla İbnü'l-Lebbân'a nispet edildiği $1^{108}$ sonra da aynı hatanın Zürkânî ve Subhî es-Sâlih tarafından tekrarlandığı görülmektedir. ${ }^{109}$ Gerçekten bu anlayışı merkeze koyduğumuzda ilahî sıfatları ve fiilleri nispeten anlayabiliriz. Örneğin, "Siz ancak Allah'in yüzünü umarak harcarsınız." bunun, insanın razı olduğuna yüzünü dönmesi teamülünden alındığını söyleyebiliriz. O halde Allah'ın gadabnın da, insanın kızdığ kişiden yüzünü çevirme teamülüne bağlı olarak kızgınlıktan kinaye olduğunu söylemek mümkündür. O zaman "Allah kıyamet günü onlarla konuşmayacak, onlara bakmayacak" gibi konuşmamak, bakmamak ifadelerinin Kur'ân'da bu anlamda kullanıldığı söylenebilir.

Sıfatlarla ilgili nasları yanlış yorumlayıp te'vîl yolunu tutan ehli bid'ate karşı İbnü'l-Arabî müteşâbihleri Kitap ve sünnetteki tasrihat ve işaretleri, Arap dilindeki kullanımları esas alarak yorumlama yoluna gitmesinin, her ne kadar bazılarında aşırıya kaçsa da kayda değer olduğu söylenebilir. Örneğin, o hidayeti, “Gerçekten size Allah'tan bir nur ve açık bir kitap geldi. Onunla Allah, rızasının peşinde gidenleri esenlik

103 Ebû Muhammed Muvaffakuddîn Abdullah b. Ahmed b. Muhammed İbn Kudâme, Zemmü't-te'vîl (Suudi Arabistan: Dârü'l-Feth, ts.), 8.

104 Takıyyüddin Ebü'l-Abbas Ahmed b. Abdülhalim İbn Teymiyye, 'Arşü’r-Raḥmân (Beyrut: Dârü'lUlûmi'l-Arabiyye, 1995), 68-76.

105 İbn Kayyim el-Cevziyye, Muhtașaru'ṣ-șavấikị'l-mürsele 'ale'l-Cehmiyye ve'l-Mu'ațțla (Riyâd: Advâü'sSelef, ts.), $1 / 43$.

106 eș-Şûrâ 42/11.

107 Muhyiddin İbnü'l-Arabî, Reddü me`âni'l-âyâti'l-müteşâbihât ilâ me'âni'l-âyâti'l-muhkemât (Beyrut: Nadi Kütübü'l-Arabiyye, 1328), 5-6.

108 Celâleddin es-Süyûtî, el-İtkān fí 'ulûmi'l-Ḳur’ân (Beyrut: Dâru İbn Kesîr, 1987), 1/652-658.

109 bk. Muhammed Abdülazîm Zürkânî, Menâhilü'l-cirfân fí ‘ulûmi'l-Kur’ân (Beyrut: Dârü'l-Ma'rife, 2005), 2/ 180-181; Subhî es-Sâlih, Mebâhis fí 'ulûmi'l-Kur'ân (Beyrut: Dâru'l-ìlm li'l-Melâyin, 2000), 285-286.

110 el-Bakara 2/272. 
yollarına iletir." ${ }^{111}$ ayeti gereğince, resullerin şeriatı vasıtasıyla kalplere tecelli ettiğgi nuru olduğunu; hicabının da, "Hayır, onların işleyip kazandıkları şeyler, kalplerinin üzerine pas olmuştur. Hayır, doğrusu o gün onlar Rablerinden perdelenmişlerdir." 112 ayetleri gereğince ateşten yaratılan şeytanî mahlûkların vesveselerinden hâsıl olan örtü olduğunu söylemektedir. ${ }^{113}$

İbnü'l-Arabî "Allah göklerin ve yerin nurudur."114 ayeti gereğince Allah'in yedinin (eli) emir âleminden olan kayyumiyet (varlıkları ayakta tutan) sıfatılla mevsuf olan nuru olduğunu söyler. ${ }^{115}$ O, Yâsîn sûresinin 36/71 ayetinde Allah için "eydînâ" şeklinde çoğul formatının kullanılmasını elin hakiki anlamda kullanılmadığının delili sayar. Buna göre Allah'a ellerin nispet edilmesi, kendisinden tasarruf, ilk yaratma ve iade yönüyle tutuş (yani yaratmasın)ın zuhur ettiği yüksek ulvî nurların hakikatine ait olan bir istiâredir. ${ }^{116} \mathrm{~Hz}$. Âdem'in yaratılmasında kullandığı iki elinin hakikati ise, fadl ve adl sıfatıyla kaim olan Allah'in kudret nuruna ait bir istiâredir. ${ }^{117}$ Allah'ın fevkiyeti, manevi yüksekliğini, istivâsı, eşit anlamında "seviye"den olduğunu ve Allah'ın yaratılıs ve emir âleminde adaletle iş yapması ve varlıkları ölçüyle icat etmesini ifade eder. ${ }^{118}$ Allah'ın varlıklarla maiyyetini (beraberliğini) ifade eden ayetlerdeki hakikat ise bir sayısının bütün sayılarda bulunma keyfiyeti gibi temsilî bir durum olduğunu söyler. Çünkü hiçbir sayı birsiz değildir; ikide iki, üçte üç, beşte beș adet bir vardır. ${ }^{119}$

Aslında ilahî sıfatların birer temsilî ifade olduğunu daha önce Zemahşerî ve Fahreddin er-Râzî gibi ulema da dile getirmişlerdi. Örneğin, Zemahşerî "Şüphesiz lütuf Allah'in elindedir." ${ }^{20}$ ayetinde "el" ifadesinin "mülkünde ve tasarrufundadır" anlamında bir temsilî anlatım olduğunu söylemektedir. ${ }^{121}$ Bu bağlamda elin kullanılmasını insan teamülünü esas aldığımızda iyiliğin elle yapması nüktesinden dolay1 olduğu söylenebilir. Aynı durum "Gözlerimiz (gözetimimiz) altında gemiyi yap." 122 ayetinde de vardır. İbn Atıyye el-Endelüsî̀ye göre, gözlerin idrâk, gözetmek ve hıfz anlamında, çoğul olmasının da azamet (büyüklük) anlamında olduğunu söyler. ${ }^{123}$ Râzîye göre ayette "göz" gözetmek anlamında olup bir şeye önem veren birinin ona gözünü dikmesi ilgisinden dolayı göz, gözetmek anlamında kullanılmıştır; çoğul

\footnotetext{
111 el-Mâide 5/15-16.

112 el-Mutaffifîn 83/14-15.

113 İbnü'l-Arabî, Reddü me âni'l-âyâti'l-müteşâbihât, 11-12.

114 en-Nûr 24/35.

115 İbnü'l-Arabî, Reddü me âni'l-âyâti'l-müteşâbihât, 25.

116 İbnü'l-Arabî, Reddü méâni'l-âyâti'l-müteşâbihât, 22.

117 İbnü'l-Arabî, Reddü me âni'l-âyâti'l-müteșâbihât, 22-23.

118 İbnü'l-Arabî, Reddü me âni'l-âyâti'l-müteşâbihât, 36, 46-47.

119 İbnü'l-Arabî, Reddü me âni'l-âyâti'l-müteşâbihât, 52.

120 el-Hadîd 59/29

121 Zemahşerî, el-Keşşâf, 4/484.

122 Hûd 11/37.

123 İbn Atiyye, el-Muharrerü'l-vecîz, 3/169.
} 
olması da mübalağa (özen) içindir. ${ }^{124}$ Aynı şekilde Zemahşerî’ye göre "Rabbin (emri) ve melekler saf saf geldiğinde" 125 ayetinde gelişin Allah'a isnadının, Allah'ın iktidar (saltanat), otorite ve hâkimiyetinin ortaya çıkışını ifade eden bir temsilî anlatımdır. Bu da, krallar bir yere teşrif ettiklerinde, asker ve vezirlerinin cümbür cemaat hazır bulunmalarında olmayan bir heybet ve siyasetin görüleceği durumuna benzetilmiştir. ${ }^{126}$ Bu bakış açısı esas alınmadığı takdirde “(O gün) Rabb'inin arşını onların üstündeki sekiz melek taşır." 127 gibi bazı ayetlere izahat getirilemez.

O halde Allah'ın Kur'ân'da kendisine el, yüz, göz vs. uzuvlar nispet etmesinin temsilî, insan biçimci bir anlatım olduğu söylenebilir. İnsan hiçbir şeyin kendisine benzemeyen Allah'ı tasavvur edememe zorunluluğundan dolayı dinin bu tarz anlatımı tercih ettiği ifade edilebilir. Kendisinden önceki müfessirlerden bazılarının bu konuda bazı yorumları olsa da temsilî anlatımla ilgili İbnü’l-Arabî̀nin bir sistem geliştirdiği söylenebilr.

Ancak biz makalemizin bundan sonraki kısmında ikilem arz eden, Râgıb elİsfahânî’nin el-ahkâmü'l-ğllka dediği ${ }^{128}$ müteşâbihat kategorisinden bazı Kur'ân ayetlerini nasıl anlamak gerektiği üzerinde duracağı. Kanaatimizce bu konuda iki yol takip edebiliriz.

\subsection{Müteşâbihleri Muhkemlere İrca Etmek}

Herhangi bir metni sahih olarak anlamak onu kendi bütünlüğü içinde değerlendirmekle mümkündür. Din bütünlüğünden bağımsız tikel olarak Kur'ân ayetleri ve hadisler sıhhatli olarak anlaşılmaz. Bütüncül yorumlama Kur'ân ve sünnetin ruhuna uygun, onlarla çelişmeyen bir istinbat yoludur. Müteşâbih ayetlerin de Kur'ân ve sünnet bütünlüğü içinde anlaşılabilmesi için onların muhkem ayetlere irca edilmesi gerekmektedir.

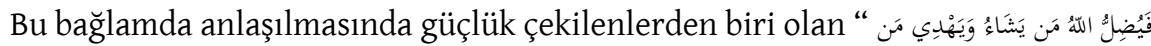
“يَّاءُ “Allah, dilediğini dalalete dilediğini de hidayete erdirir." 129 ayetinde dalalet meşieti (dileği) kula mı, Allah'a mı aittir? Her iki ihtimal de eşit olup ayette bir müteşâbih-

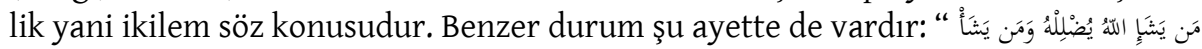

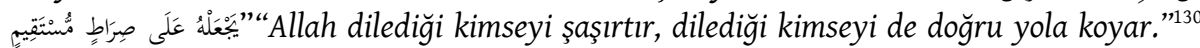
ayetinde direkt olarak dalalet ve doğru yola erdirme meşieti Allah'a verilmektedir. Mu'tezile burada dalâletin tesmiye cihetiyle olduğunu yani Allah'ın dalaleti işleyeni

\footnotetext{
124 Fahreddin er-Râzî, et-Tefsirü'l-kebîr, 6/344.

125 el-Fecr 89/22.

126 Zemahşerî, el-Keşşâf, 4/751.

127 el-Hâkka 69/17. Ayrıca bk. el-Mülk 67/16.

128 Râgıb el-i̇sfahânî, el-Müfredât, 255.

129 İbrâhîm $14 / 4$.

130 el-En`âm 6/102.
} 
ehli dalalet olarak nitelediğini ve bu şekilde hükmettiğini ifade etmektedir. ${ }^{131}$

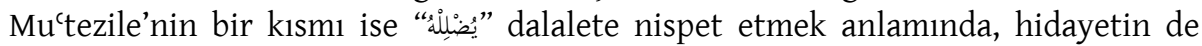
beyanda bulunma ve yol gösterme anlamında olduğunu söyleyerek ${ }^{132}$ dalalet ve hidayeti birbirinden farklı değerlendirmektedir. İbn Kuteybe ise Arap dilinde bir kimseye dalalet nispet edildiğinde tef'îl babından " "ض." denilmesinin gerektiğini, ayet ifadesinin ise if âl babından geldiğinden böyle bir anlamın doğru olmadığını söylemektedir. ${ }^{133} \mathrm{O}$ halde metodumuz olan "mütaşâbihlerin muhkemlere irca" edilmesi kâidesinden hareketle bu tarz problemleri çözmeye çalışacağız:

Aşağıdaki ayet muhkem olup bu meşietin Allah'a ait olduğunu ve bunu kullanma keyfiyetini bize açıklamaktadır:

“Onunla (Kur'ân'la) Allah, rızasının peşinde gidenleri esenlik yollarına iletir ve onları kendi izniyle karanlıklardan aydınliğa çıkarıp dosdoğru bir yola iletir."134 ayeti bize Allah'ın, Kur'ân'la rızasını öğrenip ona uygun davrananı selamet yollarına erdireceğini ifade etmektedir. O halde dalalet ve hidayet Allah'a ait olup Allah'in bunu iyilik ve kötülük doğrultusunda hareket eden kimsenin leh ve aleyhinde kullandığı anla-

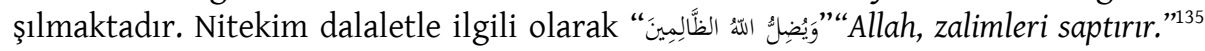
denilmekte ve aynı şekilde, “' Allah, yalancı, nankör insanı doğru yola iletmez." ${ }^{136}$ buyurulmaktadır. Demek ki ilahi meşiete aykırı davranıp zulüm, yalan ve nankörlük yoluna sapanları Allah saptırmakta, doğru yola sevk etmemektedir. Buna göre Allah'ın saptırması, kulun kötülüğü dilemesi, zulüm, yalan

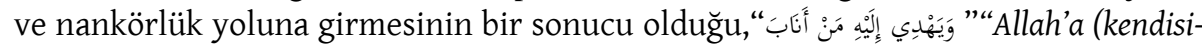
ne) yönelenleri doğru yola iletir." ${ }^{\prime 137}$ ayetinde olduğu gibi hidayetin de, kulun iyiye yönelmesinin neticesi olduğu anlaşılmaktadır. Aslında Allah'ın kulları için asla

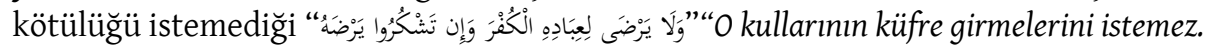
Eğer şükkrederseniz (yani inanırsanız sizin adınıza) hoşnut olur." ${ }^{\prime 18}$ ayetinden anlaşılmaktadır. Ancak kul tarafından sapkınlık tercih edilir ve bu konuda bir meyil ortaya konulursa istememekle beraber Allah onun için dalaleti yarattığ 1 söylenebilir. O halde kul kötülügü ister ve bu konuda meyil gösterirse Allah istememekle beraber kulu dalalete; iyiliği isteyip, bu konuda meyil gösterirse Allah onu da istediği doğrultuda hidayete erdirir. Bize göre bu, Kur'ân ve din bütünlüğüne en uygun olan yorumdur.

\footnotetext{
131 İbn Kuteybe, Te vî̂lü müşkili'l-Ḳur’ân, 80.

132 İbn Kuteybe, Te’vîlü müşkili'l-Ḳur’ân, 80.

133 İbn Kuteybe, Te vîlü müşkili'l-Kur ân, 80.

134 el-Mâide 5/16.

135 İbrâhîm 14/27.

136 ez-Zümer 39/3.

137 er-Ra'd 13/27.

138 ez-Zümer 39/7.
} 
Yine, “' “بllah bütün günahları affeder."139 ayetine lafzî olarak bakıldığında Allah'ı bir kimseyi hiçbir neden olmaksızın affedebileceği anlaşılmaktadır. Ancak amel ve eğilimin etkisi yok mudur? O halde bundaki ikilemi yine onu muhkem ayetlere irca etmekle çözebiliriz. "Ben, tövbe eden, inanan ve yararl iş yapan, sonra da yola gelen kimseye karşı çok bağışlayıctyımdır." ${ }^{140}$ ayetinde günahlarına samimi tövbe edip yararlı işlerle uğraşan ve hidayet üzerinde sabitkadem olanları Allah'ın affedeceği anlaşılmaktadır.

Aynı şekilde "Şüphesiz iman edenler; Yahudiler, Hıristiyanlar ve Sâbiiler, bunlardan her kim, Allah'a ve ahiret gününe inanir, iyi bir iş yaparsa elbette onlara, Rableri katında mükâfat vardır; onlara korku yoktur ve onlar üzülmeyeceklerdir." ${ }^{141}$ ayetinde görünürde bir problem vardır. Bu sayılan dinlerin mensupları sanki Allah Resûlüne (s.a.v.) iman etmezlerse bile Allah'a ve ahiret gününe inanır, iyi bir iş yaparsa kurtuluşa erecekleri ifade edilmiştir. Bu ise Allah Resûlü'ne iman etmeyi şart kılan birçok ayetle çelişmektedir. ${ }^{142}$ İbn Teymiyye'ye göre Allah bu ayette önce ve sonrakilerden ve daha sonra gelecek olanlardan saadet ehlinin niteliklerini dile getirmektedir. Ayette dile getirilen dinlere mensup olanlardan bazıları Allah'a ve ahiret gününe iman edip, ameli salihte bulunuyorlardı. Ayet, bunların Allah yanında ücretleri olduğunu, geçmişlerinden mahzun, geleceklerinden korkularının olmayacağını ifade etmektedir. ${ }^{143}$ İbn Teymiyye bazılarının bu ayeti anlamayarak birtakım zayıf görüşler serdettiklerini belirtir. "Şüphesiz iman edenler; Yahudiler, Hiristiyanlar ve Sâbiîler..." ifadesi Allah Resûlü'nün bisetinden önce olsa da bu adlara dâhil olan herkesi mi kapsar? Yoksa onun bisetinden, kendisiyle birlikte gönderilen emir, nehiyden sonra olan kişilere mi hastır? Şüphesiz bu emir ve nehiyler kendi diliyle gönderildiği kişilere yapılmıştır. Bunlar da Allah Resûlü (s.a.v.) gönderilip risalet haberinin kendilerine ulaştığı ve kıyamete kadar gelecek olan kimselerdir. Demek ki bu kimseler Allah'in,“...Bu Kur'ân sizi ve eriștiği herkesi uyarayım diye bana vahiy olundu..." ${ }^{144}$ ayetinde dile getirdiği gibi Kur'ân'ın kendisine ulaştığı herkestir. ${ }^{145}$ Buna göre ayet âmm olup Allah Resûlü'nün bisetinden önce dile getirilenlerin de hepsini içermektedir. Bu yorum hem ayetin lafzına, hem siyak ve sibakına uyan, hem selefin görüșüne hem de ayetin sebeb-i nüzulüne uygun olan bir yorumdur. ${ }^{146}$ Bütün bunlardan kim bi'setinden sonra Allah Resûlü'ne inanırsa, hak bir elçiye iman ettiği için geçmişteki imanı ve iyilikleri inkâr edilmeyecek, ona iki sefer ücret ödeneceği anlaşılmaktadır. Nitekim Allah Resûlü Herakles'e yazdığı mektupta "Ben seni Müs-

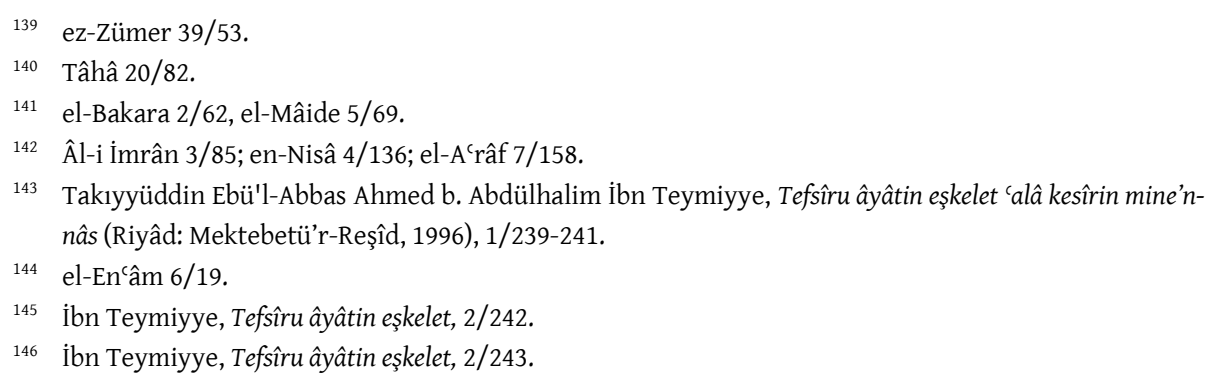


lüman olmaya davet ediyorum. Müslüman ol ki Allah sana ücretini iki sefer versin." 147 buyurarak bu gerçeği vurgulamıștır. Söz konusu bu durum Kur'ân'da da şöyle ifade edilmektedir: "Onlara (Kur'ân) okunduğu zaman: 'Ona inandık, o, Rabbimizden gelen gerçektir... Zaten Biz ondan önce de Müslümanlar idik' derler. İşte onlara, sabretmelerinden ötürü mükâfatları iki kere verilir; onlar kötülüğü iyilikle savarlar ve kendilerine verdiğimiz rızıktan (hayır yoluna) harcarlar."148 Ayette görüldüğü gibi yaptıklarına karşılık mükâfat verilen ehl-i kitabın Kur'ân'a iman edenler olduğu anlaşılmaktadır. Nitekim Kur'ân'da Yahudi ve Hiristiyanlardan bahsedildikten sonra, "Kim din olarak İslâm'dan başkasina tabi olursa bu ondan kabul edilmez ve o ahirette de ziyana uğrayanlardan olur." denmesi, ${ }^{149}$ aynı şekilde Hz. Âdem (as) ve eşi cennetten çıkarıldıktan sonra onlara, "Hepiniz oradan inin' dedik, 'Yalnız (iyi bilin ki) size benden bir hidayet geldiğ zaman, kimler benim hidayetime uyarsa artık onlara bir korku yoktur ve onlar üzülmeyeceklerdir." ${ }^{150}$ denmesi Kur'ân'a ve dolayısıyla Peygambere (s.a.v.) iman etme zorunluluğunu ortaya koymaktadır.

Nihayet şu ayet bu gerçeği bütün açıklığıyla pekiştirmekte ve Allah Resûlü'ne inanmayanı lanete uğrayanlar olarak değerlendirmektedir:

“Iman ettikten, Resul'ün hak olduğunu gördükten ve kendilerine açı deliller geldikten sonra, inkâr eden bir kavme Allah nasll yol gösterir? Allah, zalim, kavmi doğru yola iletmez. İște onların cezası: Allah'ın, meleklerin ve bütün insanların laneti onların üzerinedir! O (lanet)in içinde ebedi kalacaklardır. Onlardan azap hafifletilmeyecek ve onlara asla firsat verilmeyecektir. Ancak ondan sonra, tövde edip uslananlar başka. Çünkü Allah, çok bağışlayan, çok esirgeyendir." ${ }^{151}$

\subsection{Kur'ân'ın Âdet ve Üslubunu Bilmek}

Kur'ân'ın âdet ve üslubunu bilmek müteşâbihlerin anlamını belirlemede önemlidir. İbn Teymiyye "Birisi konuşanı tanımazsa onun kelamında kastettiği anlamı gerçek olarak idrak edemez.” der. Çünkü lafız, söz sahibinin kullandığı dil, alışık olduğu hitap tarzı ve örfü bilindiği zaman gerçek bir delalet kazanır. Konuşan kişi bilinirse konuştuğu kelamın anlamı, onun kastı da bilinir. Bu da ancak "Kur'ân metninin bütünlüğü" ve "Kur'ân lafzının geçtiği metinsel bağlamdaki söz akışı" esas alınmakla mümkündür. ${ }^{152}$ Bundan dolayı bir Kur'ân ayeti ve hadis zikredildiğinde Allah ve Resulünün (s.a.v.) bu sözle ne kastettiğini anlamak için onun Kur'ân ve hadisteki benzerlerine, bu sözü kullanış âdetine bakılmalıdır. ${ }^{153}$ Örneğin, bir gün Hz. Peygam-

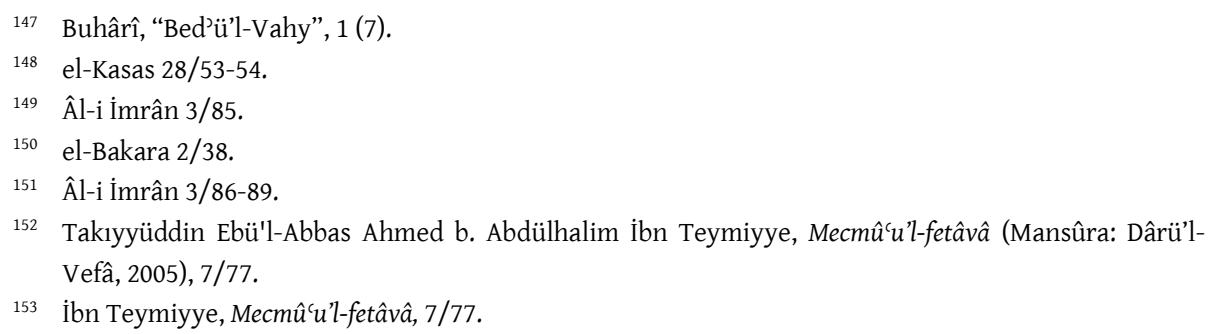


ber, yanındaki ashaba "Sizce pehlivan kimdir?" diye sordu. Yanında bulananlar, "Pehlivan, hiç kimsenin gürește yenemediği kimsedir." diye cevap verdiler. Bunun üzerine Allah Resûlü (s.a.v.) şöyle dedi: "Hayır öyle değildir; asıl pehlivan, öfkelendiğinde nefsine hâkim olan kimsedir." ${ }^{154} \mathrm{O}$ halde buna göre Allah Resûlü (s.a.v.) birisi için "Bu adam pehlivandır" dese, âdetinden ötürü bu kelamla öfkesini yenen kimseyi kastettiği anlaşılır. Kur'ân'da ise bunun en iyi örneği birçok yerde kullanılan "ökçeler/arka üzerine dönmek" tabiridir. Örneğin, "Muhammed, sadece bir elçidir. Ondan önce de elçiler gelip geçmiştir. Şimdi o ölür veya öldürülürse siz ökçelerinizin üzerinde geriye mi döneceksiniz? Kim ökçesi üzerinde geriye dönerse, Allah'a hiç bir ziyan veremez. Allah, şükredenleri mükâfatlandıracaktır."155 "Ey kavmim, Allah'in size yazdığı Kutsal Toprağa girin. Sakın arkanıza dönmeyin, yoksa ziyana uğrayanlardan olursunuz!"156 ayetlerinde olduğu gibi Kur'ân bu gibi tabirleri eski cahiliye dinine dönme anlamında kullanmaktadır. O halde ayetlerden kastedilen anlam, "Şimdi o ölür veya öldürülürse siz ökçelerinizin üzerinde geriye (yani cahiliye dinine) mi döneceksiniz?" "Sakın arkanıza (yani cahiliye dinine) dönmeyin, yoksa ziyana uğrayanlardan olursunuz." şeklindedir. Bu yüzden Kur'ân'ın âdet ve üslubunu bildiğimiz takdirde ayetlerin kastını anlar, problem olan bazı ayetleri kolaylıkla çözebiliriz.

Bu bağlamda Kur'ân'da bazen ayetlerin literal anlamılla kullanılmadığı ve bundan dolayı kastının farklı olduğunu da belirtilmek lazımdır. Kaydı-ı ittifakî denilen ifadelerin yer aldığı ayetler bu kategoridedir: “...kendileriyle birleştiğiniz eşlerinizden olup evlerinizde bulunan üvey kızlarınız size haram kılındı... "157 Herhalde üvey kızlar evde olmazsa da onlarla evlenmek helal değildir. Hukukçulara göre Kur'ân'ın bu kaydı koymasındaki kastı, bu tarz kızların genellikle üvey babalarının evlerinde yetişmiş olmalarıdır. ${ }^{158}$ "Bedelini ödeyerek hür olmak isteyen köle ve cariyelerinizin kendilerinde yarar görürseniz- tekliflerini (kitabetlerini) kabul edin." ${ }^{159}$ Köle ve cariyelerde yarar görülmese de onlarla kitabet akdinin yapılabileceğine dair hukukçular fetva vermişlerdir. ${ }^{160}$ Ancak Allah'ın bu kaydı koymaktaki kastı insanlar arasındaki teamülü bozmamak, geleneğe riayet etmektir. ${ }^{161} \mathrm{Bu}$ gibi şartı hukukçular tağlîb ve adet şartı olarak nitelemişlerdir. Çünkü galip olan adet gereğince bir insan kölelerde bir yarar gördüğü zaman böyle mükatebet akdi yapar. Ama fukahanın icmât ile kendisinde yarar olmayan kölelerle de mükatebet akdi yapılabilir. ${ }^{162}$

\footnotetext{
154 Buharî, “Edeb”, 76 (6114); Müslim,“Birr ve Sila vel-Adâb”, 107 (2609); Ebû Dâvûd. "Edeb”, 3 (4779).

155 bk. el-Bakara 2/143; Âl-i İmrân 3/144, 149.

156 el-Mâide 5/21.

157 en-Nisâ 4/23.

158 Alâaddin Abdülaziz b. Ahmed b. Muhammed el-Buhârî, Keşfü'l-esrâr 'an Ușûli fahri'l-İslâm el-Pezdevî (Beyrut: Dârü'l-Kütübi'l-i̇lmiyye, 2009), 4/290.

159 en-Nûr 24/13.

160 Ebû Bekir Şemsü'l-eimme Muhammed b. Ahmed es-Serahsî, Ușûlü's-Serahsî (Beyrut: Dârü'l-Kütübi'lİlmiyye, 2005), 2/322.

161 Serahsî, Ușûlü's-Serahsî, 2/322.

162 Serahsî, Ușûlü's-Serahsî, 2/322.
} 
Lâzımî anlam da bu kategoriye girmektedir: "Ey Yahya kitaba sımsıkı sarı""163 ifadesinden kasıt kitabın ahkâmını uygulamada titiz davranmak, "Şüphesiz Rabbin gözetlemededir." ${ }^{64}$ ifadesinden amaç da insanların davranışlarına dikkat etmelerini sağlamak olduğu söylenebilir.

Tazammunî anlam da bu kategoriye girmektedir: "Allah, size emanetleri ehline vermenizi, insanlar arasında hükmettiğiniz zaman adaletle hükmetmenizi emreder." 165 Allah'ın emanetleri ehline vermeyi emretmesi; emanetleri koruma, onları kaybetmeme, onları ihmal etmeme ve zarar vermemeyi, Allah'ın rızasının ancak emanetleri ehline teslim etmekle elde edilebileceğini de içerir. ${ }^{166}$ Yine "Içinizden hayra çağıran, iyiliği emredip kötülükten meneden bir topluluk olsun; işte onlar kurtuluşa erenlerdir." ${ }^{167}$ ayetinde iyiliği emretmek, kötülükten menetmek ifadesi, iyiliğin ve kötülügün neler olduğunu bilmeyi de gerektirir. Bütün bunlar literal olarak ayet ifadelerinde bulunmamakla beraber ayetlerin kastından anlaşılmaktadır.

Terhîbde de aynı durumun söz konusu olduğunu söylemek mümkündür. "Allah' ve elçisini incitenler var ya, işte Allah onlara dünyada ve ahirette lanet etmiş ve onlar için alçaltıcı bir azap hazırlamıştır." ${ }^{68}$ ayetinde Allah tabirinin, ona eziyet yapmanın imkânsızlığını göz önüne aldığımızda mecazî bir kullanım olduğu anlaşılmaktadır. 0 halde bu, Allah hakkında layık olmayan söz söylemek veya Allah'ın razı olmayacağı fiilleri yapmayı ya da Allah'ın sevdiği kulları incitmeyi ifade eder. ${ }^{169}$ Ancak ifadenin bu şekilde kullanılmasının kulları bu tarz davranışlardan sakındırmayı amaçladığı söylenebilir. Nitekim "Eğer böyle yapmazsanız (Yani faizi terk etmezseniz), Allah ve elçisiyle savaşa girdiğinizi bilin..."170 ayetinde de savaş ifadesinin kullanılmasının terhîb için olduğunu söylemek mümkündür.

O halde kişiyi ikileme sokan şefaat ayetlerinde de benzer durumun olduğu söylenebilir. Aslında şefaati reddeden ayetlerin nüzul ortamıla yakın alakası bulunmaktadır. Nüzûl ortamındaki müşrikler, putları kendileri ile Allah arasında şefaatçi olarak kabul ediyor ve şöyle diyorlardı: "Biz onlara sadece, bizi Allah'a yaklaştırsınlar diye ibadet ediyoruz." 171 Şefaate karşı Kur'ân'ın birtakım ayetlerinde olumsuz bir tavır olmasının geri planında bu düşüncenin olduğu söylenebilir. Allah bu düşünceyi reddetme bağlamında "O'ndan başka (tanrı diye) yalvardıkları şeyler şefaat (gücüne ve yetkisin)e sahip değillerdir. Ancak bilerek hakka şahitlik edenler (bildiklerini doğru anlatan-

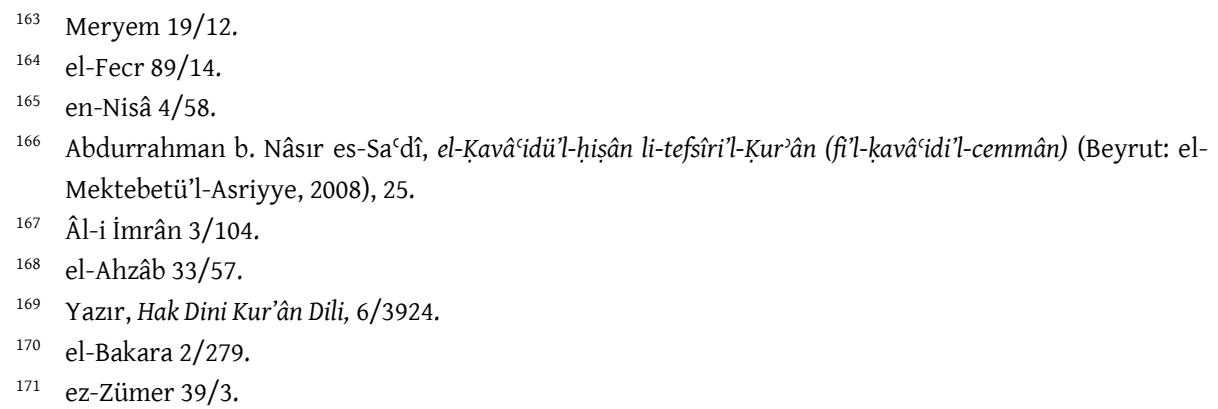


lar) bunun dışındadır."172 demekte ve müşriklerin inandıkları putların değil, Hakka şehadette bulunan doğruluk ehlinin, imanla şereflenen salihlerin şefaatte bulunacağını ifade etmektedir.

"Ey inananlar! Ne alşsverişin, ne dostluğun ve ne de şefaatin olduğu gün gelmezden önce, size verdiğimiz rızıktan (Allah için) harcayın. Kâfirler, zalimlerin ta kendileridir." 173 "Ve öyle bir günden sakının ki, o gün hiç kimse, kimsenin cezasını çekmez; kimseden şefaat da kabul edilmez; kimseden fidye de alınmaz ve onlara hiçbir yardım yapılmaz."174 ayetlerinde de şefaatin olamayacağı ifade edilmektedir. Taberî ve İbn Atiyye gibi müfessirler bağlamı esas alarak bu ifadenin İsrâiloğullarına bir hitap olduğunu, dolayısıyla şefaatin onlar için söz konusu olmayacağını ifade etmektedirler. ${ }^{175}$ Kur'ân'ın başka ayetlerinde şefaatin inananlar için söz konusu olacağı ve bunun Allah'ın iznine tabi olduğu ifade edilmektedir:

"O gün Rahman'in izin verip sözünden hoşlandığı kimseden başkasının şefaati fayda vermez."176

"Yalnız Rahman'ın huzurunda söz almış olanlardan başkaları şefaat edemezler."

Bundan dolayı Abdurrahmân es-Sacdî (ö. 1956) şefaati nefyeden ayetlerin Allah'ın izni olmadan ve kendilerinden razı olmayanlara yapılan şefaati ifade ettiğini söyler. ${ }^{178}$ Demek ki şefaat ayetlerinde şefaatin Allah'ın dileğine bağlı olduğu, bu konuda Allah'ın kendisinden razı olduğu ve kendilerine ruhsat verilen kişilerin şefaat edebilecekleri anlaşılmaktadır. Nitekim hadislerde insanlara dürüst davranma, onlara karşı hüsnü niyetli olma ve ibadetlere teşvik etme bağlamında bazı ifadelerin terhîb bağlamında kullanılması bunun delili olmaktadır. ${ }^{179} \mathrm{O}$ halde şefaati

172 ez-Zuhrûf 43/86.

173 el-Bakara 2/254.

174 el-Bakara 2/48, 123.

175 Taberî, Câmi'u'l-beyân, 2/396; İbn Atiyye, el-Muharrerü'l-vecîz, 2/339.

176 Tâ hâ 20/109

177 Meryem 19/87.

178 Sa'dî, el-Kavấcidü'l-hiṣân, 29.

179 Allah Resûlü’nün (s.a.v.), من غشنا فليس منا “Bizi aldatan bizden değildir.” (Müslim, “İman”, 164 [No. 102]; "Büyû́c" 74 [No. 1315]) hadisi literal olarak aldatan kişinin Müslüman olmadı̆̆ını ifade etmektedir. Ancak bunun, Allah Resûlü'nün (s.a.v.) bir terhîb (korkutma) üslûbu olduğu söylenebilir. Çünkü aldatmak bir günah eylemi olup bunu irtikâp eden bir günah işlemektedir. Günah işlemek ise insanı لا لائون أحدكم dinden çıkarmaz ancak ideal anlamda bir Müslüman olmadığına delalet eder. Aynı şekilde "Biriniz kendisi için sevip arzu ettiği şeyi din kardeşi için de arzu etmedikçe iman etmiş olmaz” (Buhârî, “İman”, 7 [No. 13]) hadisi literal tercüme edilse bu davranışı sergileyenin Müslüman olmadığı anlaşılır. Hâlbuki Allah Resûlü’nün (s.a.v.) amacı bu davranışı sergileyenin ideal anlamda bir mümin olmadığını ifade etmektir. Ancak bu davranışı sergilemekten alıkoymak için bu üslûbu

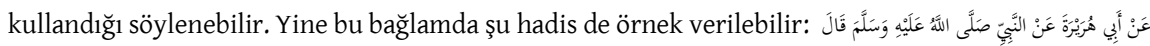
لَحaman zaman düşünüyorum namazın ikame 
nefyeden ayetlerin, bunun gibi terhîb amaçlı olduğunu söylemek mümkündür. Ayrıca yedi ayette şefaatten bahsedip bunun Allah iznine tabi olduğunu ifade etmek onun olacağının delilini saymak lazımdır. Çünkü şefaat olmasaydı bu derece şefaatten söz edilmezdi. Muteber hadis kaynaklarından birçoğunun ahirette şefaatin olacağını belirtmesi de bunu pekiştirmektedir. ${ }^{180}$ Ayrıca Allah Resûlü’nün (s.a.v) "Her peygamberin kabul edilecek bir duası vardır. Onlar bu duayı yaptılar ve kabul edildi. Ben ise duamı kıyamet günü ümmetime şefaat olarak sakladım." ${ }^{181}$ hadisi şefaatin olacağına delalet etmektedir. Ancak bu, birisine yap diğerine yapma anlamında değildir. Topyekûn bütün ümmetin günahkârları için olan bir şefaattir. Ehl-i sünnet düşüncesi gereğince Allah Resûlü'nden başka, peygamberler, melekler ve şehitler şefaat edeceklerdir. Bu da salih olmanın bereketidir. Mü'min sûresi 40/7-8. ayetleri meleklerin ve salihlerin şefaatinin iman edip, kurtuluşa erdikleri takdirde aile fertlerine şefaatçi olacakları ve bulundukları dereceye aile fertlerinin getirilip kendilerine katılacakları ve bu şekilde aile bağlarının cennette de devam edeceğine delalet etmektedir. Şefaat bir nevi şefaat ehlini onore etmek ve tabiri caizse Allah'ın, kullarını affetmesi için bir bahanesidir. $O$ halde şefaatin olamayacağına dair ayetlerin sadece terhîb (korkutma) amaçlı olup şefaate bel bağlamamayı, bunun yerine dört elle amele sarılmayı teşvik etmek amaçlı olduğu söylenebilir.

\section{Sonuç}

Kur'ân ümmilere inen bir kitap olmakla beraber çok yoğun tarzda mecazı kullanması ona hem edebî zevki olanların dikkatini çekme başarısını hem de çok anlamlılık kazandırmıştır. Kur'ân mecazlarında beşerinkilerden farklı olarak bazı evrensel hakikatleri de içerebileceği, bazı ayetlerin iniş sebepleri nüzul ortamındaki tikel olaylarla irtibatlandırılsa da mecazî kullanımlarında evrensel hakikatlere işaret edilebileceği, tarihsel gibi görünen bazı ayetlerde de evrensel mesajlar verilebileceğini göz ardı etmemek lazımdır. Kur'ân'da daha çok mecazın çok boyutlusu olan temsilî anlatım kullanılmıştır. Bununla insan ufkunu aşan gaybî hakikatlerin anlaşılır kılındığını, insanın anlayışına bu yolla dinî hakikatlerin yaklaştırıldığını söylemek mümkündür. İlahî sıfatlarla ilgili müteşâbihlerin anlaşılması ise İslâm'ın erken döneminde ihtiyatlı yaklaşılarak tevakkuf ve tefviz yolu tercih edilmiş ancak bu tercih tarih boyunca münakaşalara da neden olmuştur. Sıfatları olduğu gibi kabul edip yorum yapmaktan çekinen Selef, bunları ilâhî azamet ve sıfatlara uygun te'vîl eden halef ve İbnü'l-Arabî’nin öncülük ettiği insan-biçimci birer temsilî anlatım

edilmesini emredeyim. Ben de geriye dönüp namaza iştirak etmeyenlerin evlerini başlarına yakayım." (Buharî, "Ezân”, 29 [No. 644]; Müslim, "Mesâcid", 251 [651]) Cemaat namazına iştirak etmediği için Allah Resûlü'nün kimsenin evini başına yıkmadığını peygamberin âdetinden biliyoruz. Bütün bunlar terhib üslûbuyla ilgili söylenmiş sözler olup bunlardaki peygamber amacını anlamak için âdetini bilmenin lazım olduğu anlaşılmaktadır.

180 bk. Tirmizî, "Sifatü'l-Kiyâme”, 11 (No. 2446); Buhârî, “Tevhîd”, 24 (No. 7449).

181 Buhârî, "Daâvât”, 1 (No. 6304), "Tevhîd”, 31 (No. 7474); Müslim, "İmân”, 334 (No. 198); Ebû Abdullah Muhammed b. Yezîd İbn Mâce, es-Sünen (Riyâd: Mektebetü'l-Meârif, ts.), "Zühd” 37 (No. 4307). 
olduğunu savunan görüş olarak üçe taksim etmek mümkündür. Özellikle temsilî anlatımın Kur'ân'ı anlamada gayet fonksiyonel ve ikna edici olduğunu kabul etmek lazımdır. Bunun dini hakikatleri ifade etmede edebî zevki esas aldığı anlaşılmaktadır. Çok yoğun kullanılmasından dolayı temsilî anlatımın bir nevi din dili olduğunu söylemek mümkündür. Müteşâbih ayetlerin ikilemlerini gidermede ise bunları muhkemlere irca etmek ve Kur'ân'ın kasıt ve üslubunu bilmek önemlidir. Hidayet ve dalalet meşietinin Allah'a izafe edilmesi bu tarz olup dalalet meşietinin kulun dalalet ve kötülüğü seçmesinin bir sonucu olduğu muhkem ayetlerden anlaşmaktadır. Şefaatın olacağını ifade eden ayetlerle nefyeden ayetlerin birlikte Kur'ân'da varlığ da bizi ikileme sokmakta ancak Kur'ân ve hadislerde zaman zaman terhib üslubunun kullanıldığı dikkate alındığında nefyeden ayetlerde bu üslubun kullanıldığı anlaşılmaktadır. 


\section{Kaynakça}

Ahmed b. Hanbel, Ebû Abdullah Ahmed b. Muhammed b. Hanbel eş-Şeybânî. elMüsned. 6 cilt. İstanbul: Çağrı Yayınları, 1992.

Âlûsî, Ebü'l-Fadl Şihâbüddîn. Rûhu'l-me'ânî. 15. cilt. Beyrut: Dârü'l-Fikr, 1987.

Aristoteles. Sofistlerin Çürütmeleri Üzerine. çev. Oğuz Özügül. İstanbul: Say Yayınları, 2007.

Arpa, Abdulmuttalip. “Zâhirîlik ve Mecâz: İbn Hazm Örneği”. Sakarya Üniversitesi İlahiyat Fakültesi Dergisi 14/25 (2012), 43-67.

Beydavî, Nâsıruddîn Ebû Saîd Abdullah b. Ömer b. Muhammed Envâru't-tenzîl ve esrâru't-te'vîl. 3.cilt. Beyrut: Dâru'r-Reşîd, 2000.

Buhârî, Alâuddîn Abdülaziz b. Ahmed b. Muhammed. Keşfü'l-esrâr 'an Ușûli fahri'lİslâm el-Pezdevî. 4. cilt. Beyrut: Dârü'l-Kütübi'l-ìlmiyye, 2009.

Buhârî, Ebû Abdullah Muhammed b. İsmail. el-Câmi'u'ṣ-șahîh. Riyâd: Mektebetü'rRüşd, 2006.

Cürcânî, Ebü'l-Hasen Ali b. Muhammed Seyyid Şerîf. et-Ta'rîfât. İstanbul: y.y., ts.

Çă̆ıl, Necdet. “Hakikat-Mecaz Kutuplaşması Baglamında) Kur’ân'da Temsilî (Simgesel) Anlatım”. İslami İlimler Dergisi 8/1 (2013), 93-112.

Dihlevî, Şah Veliyyullah. el-Fevzü'l-kebîr fî ușûlîtt-tefsîr. Dimeşk: Dâru'l-Gavsânî, 2008.

Dihlevî, Şah Veliyyullah. Te’vîlâtü'l-ehâdîs. Pakistân: Akâdemiyyetü Şah Veliyyullah ed-Dihlevî, 1966.

Ebû Dâvûd, Süleyman b. Eş`as es-Sicistânî. es-Sünen. 5 cilt. İstanbul: Çağrı Yayınları, 1992.

Fahreddin er-Râzî. et-Tefsîrü'l-kebîr. 11 cilt. Beyrut: Dâru İhyầi't-Türâsi'l-Arabî, 1998.

Goldziher, Ignaz. Muslim Studies. 2. cilt. London: George Allen and Unwin, 1971.

Güllüce, Veysel. "Kâmin Mesellerin Değerlendirilmesi -İbn Fadl Örneğinde-” Atatürk Üniversitesi İlahiyat Fakültesi Dergisi 25 (2006), 95-128.

Hâtib el-Kazvînî, Ebü'l-Meâli Celâleddin Muhammed b. Abdurrahman b. Ömer. elỊ̂̂ah fì 'ulûmi'l-belầga. Beyrut: Darü'l-Kütübi'l-illmiyye, 2003.

İbnü'l-Arabî, Muhyiddin. Reddü me'âni'l-âyâti'l-müteşâbihât ilâ me'âni'l-âyâti'lmuhkemât. Beyrut: Nadi Kütübü'l-Arabiyye, 1328.

İbn Atiyye, Ebû Muhammed Abdülhak. el-Muharrerü'l-vecîz. 8 cilt. Devha: Vezâretü'lEvkâf ve Şuûni'l-İslamiyye, 2008. 
İbn Kayyim el-Cevziyye. Muhtașaru'ș-șavầikịil-mürsele 'ale'l-Cehmiyye ve'l-Mu'ațțla. 2 cilt. Riyâd: Advâü's-Selef, ts.

İbn Kesîr, İmâdüddîn Ebü'l-Fidâ. el-Bidâye ve'n-nihâye. 21 cilt. Beyrut: Hecr, ts.

İbn Kesîr, İmâdüddîn Ebü'l-Fidâ. Tefsîrü'l-Kur'âni'l-'azîm. 15 cilt. Kâhire: Mektebetü Evlâdi'ş-Şeyh li't-Türâs, 2000.

İbn Kudâme, Ebû Muhammed Muvaffakuddîn Abdullah b. Ahmed b. Muhammed. Zemmü't-te'vîl. Suudi Arabistan: Dârü'l-Feth, ts.

İbn Kuteybe, Ebu Muhammed Abdullah b. Müslim. Te'vîlu müşkili'l-Kur'ân. Misır: Dâru't-Turâs, 1973.

İbn Mâce, Ebu Abdullah Muhammed b. Yezîd. es-Sünen. Riyâd: Mektebetü'l-Meârif, ts.

İbn Sacd, Ebû Abdullah Muhammed b. Sacd b. Menî‘. eț-Ṭabâkătü̈l-kübrâ. 8 cilt. Beyrut: Dâru Sâdır, ts.

İbn Sînâ, Ebû Ali. Kitâbu'ş-Şifâ: Sofistik Deliller. çev. Ömer Türker. İstanbul: Litera Yayıncllı, 2006.

İbn Teymiyye, Takiyyüddin Ebü'l-Abbas Ahmed b. Abdülhalim. Tefsîru âyâtin eşkelet 'alâ kesîrin mine'n-nâs. Riyâd: Mektebetü'r-Reşîd, 1996.

İbn Teymiyye, Takıyyüddîn Ebü'l-Abbas Ahmed b. Abdilhalim. 'Arşü'r-Rahmân. Beyrut: Dârü'l-Ulûmi'l-Arabiyye, 1995.

İbn Teymiyye, Takıyyüddîn Ebü'l-Abbas Ahmed b. Abdülhalim. el-îklîl fill-müteşâbih ve't-te'vîl. İskenderiyye: Dârü'l-İmân, 2002.

İbn Teymiyye, Takıyyüddîn Ebü'l-Abbas Ahmed b. Abdülhalim. 9 cilt. Mecmû́u'lfetâvâ. Dârü'l-Vefâ, 2005.

Kiraz, Celil. 'Zemahşeri'nin el-Keşşâf'ında Allah'ın Bazı Sıfatlarıyla ilgili Temsîl, Mecâz ve İstiâre Algılamaları". Uludağ Üniversitesi İlahiyat Fakültesi Dergisi 17/2 (2008), 519-568.

Ma'mer b. Müsennâ, Ebû Ubeyde. Mecâzü'l-Kur'ân. 2 cilt. Kâhire: Mektebetü'l-Hânci, ts.

Mâtürîdî, Ebû Mansûr Muhammed. Te’vîlâtü'l-Kuruân. 14 cilt. İstanbul: Dârü'l-Mîzân, 2005.

Mevdudî, Ebü'l-A'lâ. Tefhimü'l-Ḳurân. çev. Hamdi Aktaş. 7 cilt. İstanbul: İnsan Yayınları, 1986.

Müslim, Ebü'l-Hüseyin Muslim b. Haccâc. Șahihnu Müslim. Riyâd: Beytü'l-Efkâri'dDevlî, 1998.

Radî, Şerîf. Telhîșü'l-beyân fîmecâzâti'l-Kurâân. Beyrut: Dârü'l-Kütüb, 2011. 
Râgıb el-İsfahânî, Ebü'l-Kāsım Hüseyin b. Muhammed. el-Müfredât fî gaarîbi'l-Kur'ân. Beyrut: Darï'l-Ma'rife, ts.

Sa'dî, Abdurrahman b. Nâsır. el-Kavấcidü'l-ḥiṣân li-tefsîri'l-Kur'ân (fi'l-kavâa'idi'lcemmân). Beyrut: el-Mektebetü'l-Asriyye, 2008.

Sâlih, Subhî. Mebâhis fî 'ulûmi'l-Kur'ân. Beyrut: Dâru'l-i̇lm li'l-Melâyîn, 2000.

Serahsî, Ebû Bekr Şemsü'l-eimme Muhammed b. Ahmed. Ușûlü's-Serahsî. 2 cilt. Beyrut: Dârü'l-Kütübi'l-ílmiyye, 2005.

Süyûtî, Celâleddin. el-İtkēn fî̀ 'ulûmi'l-Kur’ân. 2 cilt. Beyrut: Dâru İbn Kesîr, 1987.

Taberânî, Ebü'l-Kâsım Süleyman b. Ahmed b. Eyyûb. el-Mu'cemü'l-kebîr. 25 cilt. Mektebü'l-Ulûm ve'l-Hikem, 1983.

Taberî, Ebu Ca'fer. Câmi'u'l-beyân 'an te'vîli âyi'l-Kur'ân. 25 cilt. Kahire: Hecr, ts.

Tehânevî, Muhammed Aclâ b. Ali el-Fârûkī. Keşşâfu ıșțlâhhâti'l-fünûn. 4 cilt. Beyrut: Dârü'l-Kütubi'l-İlmiyye, ts.

Tirmizî, Ebû İsa Muhammed b. Sevre. es-Sünen. 5 cilt. İstanbul: Çağrı Yayınları, 1992.

Vâhidî, Ebü’l-Hasan Ali b. Ahmed. Esbâbu'n-Nüzûl. Beyrut: Dâru İbn Kesîr, 1988.

Yazır, Muhammed Hamdi. Hak Dini Kur'ân Dili. 10 cilt. İstanbul: Eser Neşriyat, 1978.

Zemahşerî, Mahmud b. Ömer. el-Keşşâf 'an hakāāiḳi ġavâmiḍitt-tenzîl. 4 cilt.Beyrut: Dârü'l-Kitabi'l-Arabî, 1987.

Zürkânî, Muhammed Abdülazîm. Menâhilü'l-irfân fî ‘ulûmi'l-Kur’ân. 2 cilt. Beyrut: Dârü'l-Ma'rife, 2005.

Zerkeşî, Muhammed b. Abdullah b. Burhân. el-Burhân fì 'ulûmi'l-Kur'ân. Kahire: Dâru Türâsi'l-Arab, 1984.

Zeyd b. Ali b. Hüseyin. Ġarîbü'l-Ḳur’ân. İran: el-Mektebetü'l-í'lâmi'l-İslamî, 1418. 


\section{The Correct Methodology of Understanding Some Metaphorical and Mutashābih Verses}

\section{Extended Abstract}

As it is known, there are some difficulties in interpreting some verses. The most important of these are metaphorical verses and the verses with a profundity of meanings and a versatile content (mutashābih). Considering that the Qur'ān uses metaphors and the (mutashābih) verses that are characterized with the realm of the unseen (gayb) and which are challenging for our limited conceptualizations exist abundantly in the Holy Qur'ann, the importance of the issue becomes clear. These kinds of difficulties can not quite easily be overcome if the Qur'ān is not considered in its unity and entirety and the style is not well known in these verses. However, the Qur'ān is a word that came from the transcendent to the inherent and descended on the basis of human impulses and nature. Therefore, it is possible to understand the Qur'ān in the integrity of Islam and by knowing the nature of human beings and establishing the harmony of the Qur'ān with man.

Although the Qur'ān is a book that was revealed to the illiterate(Ummì)s, it also appeals to different people, such as those with literary taste. One of the proofs of this is that it uses metaphor quite a lot. Because metaphor expands the meaning of expressions. For this reason, metaphor performs a great function in addressing the religion to different people. A metaphor is a word and a combination used in a sense other than the meaning that it belongs to, with the presumption and the existence of a relation that prevents the real meaning from what is meant. The use of a word and a combination in this way outside of its real meaning is a harbinger of a problem, and this situation showed itself in the first period of Islam.

It can be said that representational narration prevails especially in divine attributions, and an anthropomorphic expression is preferred in this regard. We can define this as "Q1yās al-gāib alā al-shāhid", that is, to describe an unknown world by analogy with the phenomena of the known world. With this expression, it is possible to say that unseen and psychological situations that transcend the human horizon are made intelligible, and religious truths are brought closer to fehme in this way. In the Qur'ān, the representational expression of metaphor is used extensively. One part is the representational expression (this part conpains many parts of any kind of words). Representation is describing an abstract thing by comparing it to a concrete one. In the Qur'ān, on the other hand, representation is describing abstract, unseen situations by analogy with things that can be perceived and observed. We can say that conceptions states such as heaven, hell, devil, reward and punishment are explained in this way. "And We have certainly made the Qur'ān easy for remembrance, so is there any who will remember?" It can be said that the verse (al-Qamar 54/17) emphasizes this style of expression and its 
functionality in this sense, and by this means, people can perceive the high truths of the Qur’ān.

Divine attributes were also described in this way, and an anthropomorphic expression was preferred for them. Regarding divine attributes in the early period, most of the Salaf (Companions of the Prophet (pbuh) and the followers of them (tābi īn) approached them cautiously and preferred the way of tawakquf and tafwiz. As Ibn Taymiyya, who walked in the path of the predecessors, saw the interpretation of the adjectives as a kind of distortion, he accused some of the traditionalists and theologians of heresy. The successor, on the other hand, took the path of interpreting the mutashābih by bringing evidence from the language and the verses. However, Ibn al-Arabi said that the limbs attributed to God in the Qur'ān is a representational expressions and that God, a being that "nothing resembles him", is a human-formist narrative aimed at ensuring of the consonance of hearts. It should be said that this expression is significant and he has found a lot of fans lately. This is the transmission of religious truths in a high literary and symbolic style. In this way, abstract situations are brought closer to the human imagination. In fact, like Zamakhsherī and Fakhr al-Dīn al-Rāzī, some scholars had previously stated that divine attributes are representative expressions. Although some of the commentators before him had some comments on this subject, it can be said that Ibn al-Arabi developed a system for representational expression. We examined the Metaphor and the relationship between metaphor and truth, and some verses in which only metaphor is meant, and especially representational narration. On the subject of mutashābih, issues such as mutashābih, adaptation of them to Muhkāmat and understanding the Qur'ān by taking into account the style of the Qur'ān have been tried to be resolved within a methodology.

Keywords: Tafsīr, Qur’ān, Metaphor, Representational Narration, Mutashābih. 